NUREG/CR-3616

DO NOT MICROFILM ARL-124-83/M398F COVER SAND83-7471

\title{
Transport and Screen Blockage Characteristics of Reflective Metallic Insulation Materials
}

Prepared by D. N. Brocard/ARL

Alden Research Laboratory Worcester Polytechnic Institute

Sandia National Laboratories

Prepared for

U.S. Nuclear Regulatory

Commission 
NOTICE

This report was prepared as an account of work sponsored by an agency of the United States Government. Neither the United States Government nor any agency thereof, or any of their employees, makes any warranty, expressed or implied, or assumes any legal liability of re. sponsibility for any third party's use, or the results of such use, of any information, apparatus. product or process disclosed in this report, or represents that its use by such third party would not infringe privately owned rights.

\section{Availability of Reference Materials Cited in NRC Publications}

Most documents cited in NRC publications will be available from one of the following sources:

1. The NRC Public Document Room, 1717 H Street, N.W. Washington, DC 20555

2. The NRC/GPO Sales Program, U.S. Nuclear Regulatory Commission, Washington, DC 20555

3. The National Technical Information Service, Springfield, VA 22161

Although the listing that follows represents the majority of documents cited in NRC publications, it is not intended to be exhaustive.

Referenced documents available for inspection and copying for a fee from the NRC Public Document Room include NRC correspondence and irternal NRC memoranda; NRC Office of Inspection and Enforcement bulletins, circulars, information notices, inspection and investigation notices; Licensee Event Reports; vendor reports and correspondence; Commission papers; and applicant and licensee documents and correspondence.

The following documents in the NUREG series are available for purchase from the NRC/GPO Sales Program: formal NRC staff and contractor reports, NRC-sponsored conference proceedings, and NRC booklets and brochures. Also available are Regulatory Guides. NRC regulations in the Code of Federal Regulations, and Nuclear Regulatory Commission /ssuances.

Documents available from the National Technical Information Service include NUREG series reports and technical reports prepared by other federal agencies and reports prepared by the Atomic Energy Commission, forerunner agency to the Nuclear Regulatory Commission.

Documents available from public and special technical libraries include all open literature items, such as books, journal and periodical articles, and transactions. Federal Register notices, federal and state legislation, and congressional reports can usually be obtained from these libraries.

Documents such as theses, dissertations, foreign reports and translations, and non-NRC conference proceedings are available for purchase from the organization sponsoring the publication cited.

Single copies of NRC draft reports are available free upon written request to the Division of Tech. nical Information and Document Control, U.S. Nuclear Regulatory Commission, Washington, DC 20555.

Copies of industry codes and standards used in a substantive manner in the NRC regulatory process are maintained at the NRC Library, 7920 Norfolk Avenue, Bethesda, Maryland, and are available there for reference use by the public. Codes and standards are usually copyrighted and may be purchased from the originating organization or, if they are American National Standards, from the American Nationai Standards Institute, 1430 Broadway, New York, NY 10018. 


\section{DISCLAIMER}

This report was prepared as an account of work sponsored by an agency of the United States Government. Neither the United States Government nor any agency Thereof, nor any of their employees, makes any warranty, express or implied, or assumes any legal liability or responsibility for the accuracy, completeness, or usefulness of any information, apparatus, product, or process disclosed, or represents that its use would not infringe privately owned rights. Reference herein to any specific commercial product, process, or service by trade name, trademark, manufacturer, or otherwise does not necessarily constitute or imply its endorsement, recommendation, or favoring by the United States Government or any agency thereof. The views and opinions of authors expressed herein do not necessarily state or reflect those of the United States Government or any agency thereof. 


\section{DISCLAIMER}

Portions of this document may be illegible in electronic image products. Images are produced from the best available original document. 


\section{Transport and Screen Blockage Characteristics of Reflective Metallic Insulation Materials}

NUREG/CR--3616

DE84 006355

Manuscript Completed: December 1983

Date Published: January 1984

Prepared by

D. N. Brocard, Alden Research Laboratory

Alden Research Laboratory

Worcester Polytechnic Institute

Holden, MA 01520

Under Contract to

Sandia National Laboratories

Albuquerque, NM 87185

\section{Prepared for}

Division of Safety Technology

Office of Nuclear Reactor Regulation

U.S. Nuclear Regulatory Commission

Washington, D.C. 20555

NRC FIN A1296

\section{DISCLAIMER}

This report was prepared as an account of work sponsored by an agency of the United States Government. Neither the United States Government nor any agency thereof, nor any of their employees, makes any warranty, express or implied, or assumes any legal liability or responsibility for the accuracy, completeness, or usefulness of any information, apparatus, product, or process disclosed, or represents that its use would not infringe privately owned rights. Reference herein to any specific commercial product, process, or service by trade name, trademark, manufacturer, or otherwise does not necessarily constitute or imply its endorsement, recommendation, or favoring by the United States Government or any agency thereof. The views and opinions of authors expressed herein do not necessarily state or reflect those of the United States Government or any agency thereof. 


\section{NOTICE}

This report was prepared as an account of work sponsored by an agency of the United States Government. Neither the United States Government nor any agency thereof, or any of their employees, makes any warranty, expressed or implied, or assumes any legal liability of re. sponsibility for any third party's use, or the results of such use, of any information, apparatus, product or process disclosed in this report, or represents that its use by such third party would not infringe privately owned rights.

\section{Availability of Reference Materials Cited in NRC Publications}

Most documents cited in NRC publications will be available from one of the following sources:

1. The NRC Public Document Room, 1717 H Street, N.W. Washington, DC 20555

2. The NRC/GPO Sales Program, U.S. Nuclear Regulatory Commission, Washington, DC 20555

3. The National Technical Information Service, Springfield, .VA 22161

Although the listing that follows represents the majority of documents cited in NRC publications, it is not intended to be exhaustive.

Referenced documents available for inspection and copying for a fee from the NRC Public Document Room include NRC correspondence and iriternal NRC memoranda; NRC Office of Inspection and Enforcement bulletins, circulars, information notices, inspection and investigation notices; Licensee Event Reports; vendor reports and correspondence; Commission papers; and applicant and licensee documents and correspondence.

The following documents in the NUREG series are available for purchase from the NRC/GPO Sales Program: formal NAC staff and contractor reports, NRC-sponsored conference proceedings, and NRC booklets and brochures. Also available are Regulatory Guides, NRC regulations in the Code of Federal Regulations, and Nuclear Regulatory Commission /ssuances.

Documents available from the National Technical Information Service include NUREG series reports and technical reports prepared by other federal agencies and reports prepared by the Atomic Energy Commission, forerunner agency to the Nuclear Regulatory Commission.

Documents available from public and special technical libraries include all open literature items. such as books, journal and periodical articles. and transactions. Federal Register notices, federal and state legislation, and congressional reports can usually be obtained from these libraries.

Documents such as theses, dissertations, foretgn reports and translations, and non-NRC conference proceedings are available for purchase from the organization sponsoring the publication cited.

Single copies of NRC draft reports are avaitable free upon written request to the Division of Tech nical Information and Document Control, U.S. Nuclear Regulatory Commission, Washington, DC 20555.

Copies of industry codes and standards used in a substantive manner in the NRC regulatory process are maintained at the NRC Library. 7920 Norfolk Avenue, Bethesda. Maryland, and are available there for reference use by the public. Codes and standards are usually copyrighted and may be purchased from the originating organization or, if they are American National Standards, from the American National Standards Institute. 1430 Broadway. New York, NY 10018. 
$\therefore \quad \infty$ 
In the event of a LOCA within a nuclear power plant, it is possible for insulation debris to be generated by the break jet. Such debris has the potential for PWR sump screen (or BWR RHR suction inlet) blockage and thus can affect the long term recirculation capability. In addition to the variables of break jet location and orientation, the types and quantities of debris which could be generated are dependent on the insulation materials employed. This experimental investigation was limited to reflective metallic insulation and components thereof. The study was aimed at determining the flow velocities needed to transport the insulation debris to the sump screens and the resulting modes of screen blockage.

The tests revealed that thin metallic foils $\left(0.0025^{\prime \prime}\right.$ and $\left.0.004^{\prime \prime}\right)$ could transport at low flow velocities, $0.2-0.5 \mathrm{ft} / \mathrm{sec}$. Thicker foils (0.008") transported at higher velocities, $0.4-0.8 \mathrm{ft} / \mathrm{sec}$, and "as fabricated" half cylinder insulation units required velocities in excess of $1.0 \mathrm{ft} / \mathrm{sec}$ for transport.

The tests also provided information on screen blockage patterns that showed blockage could occur at the lower portion of the screen as foils readily flipped on the screen when reaching it. The tests also revealed that, although transport of foils occurred in a folding and tumbling mode, the foils did not become "water borne" and did not block the screen above their largest dimension. 


$$
\text { . }
$$


TABLE OF CONTENTS

Page No.

ABSTRACT

iii

TABLE OF CONTENTS

v

LIST OF FIGURES

vii

LIST OF TABLES

ix

ACKNOWLEDGEMENTS

$x i$

EXECUTIVE SUMMARY

1

1.0 INTRODUCTION

3

2.0 METHODOLOGY 4

2.1 Insulation Components Tested 4

2.2 Test Facility and Instrumentation 9

2.3 Testing Procedure 9

3.0 SUMMARY OF KEY FINDINGS

3.1 Transport Velocities 12

3.2 Transport Modes 12

3.3 Blockage Modes 13

3.4 Limitations 13

4. 0 RESULTS

4.1 Results for the 10 Inch Pipe Insulation Units 14

4.1 .1 Undamaged Unit 14

4.1.2 Outer Cover 15

$\begin{array}{lr}4.1 .3 \text { Inner Covers } & 15\end{array}$

$\begin{array}{lr}4.1 .4 \text { End Covers } & 15\end{array}$ 
TABLE OF CONTENTS

Page No.

4.1.5 Inner Foil

4.1.6 Separating Crimp

26

4.2 Stainless Steel Foil

26

4.2.1 0.0015 Inch Thick Foil

26

4.2.2 0.004 Inch Thick Foil

26

4.2.3 0.008 Inch Thick Foil

2.8

TABLE $\quad 4-1$

32

TABLE $4-2$

36

REFERENCES 
FIGURE 1 Schematic Drawing of Reflective Metallic Insulation Unit for 10 Inch Pipe Used in Tests

FIGURE 3 One of the Two Insulation Units Tested

FIGURE 4 Metal Clasp Attaching Reflective Metallic Insulation Units

FIGURE 5 Insulation Unit with End Cover Removed (Note Drilled Out Spotwelds) and Inner Foil Being Pulled out (Note Crimp Separator)

FIGURE 8 Possible Positions of Undamaged Insulation Unit (Half of Entire Assembly) Against Screen 16

FIGURE 9 Insulation Unit (Half of Entire Assembly) 16

FIGURE 10 Uncrumpled Inner Foil (0.0025 Inch Thickness) Being Bent and Folded by the Flow During Transport

FIGURE 11 Uncrumpled Inner Foil (0.0025 Inch Thickness) Against the Screen

FIGURE 12 Crumpled Inner Foils (0.0025 Inch Thickness) Prior to Testing

FIGURE 13 Crumpled Inner Foil (0.0025 Inch Thickness) Arrested Against the Flume Side Wall

FIGURE 14 Transport of Several Inner Foil Sheets 
viii

LIST OF FIGURES

Page No.

FIGURE 17 Folding and Tumbling Transport of 0.004 Inch Foil and Corresponding screen Blockage

FIGURE 18 Screen Blockage Patterns Obtained with Uncrumpled 0.004 Inch Foils (36 X 36 Inch Sheets)

FIGURE 19 Sliding Transport and Corresponding Screen Blockage of Single 0.008 Inch Thick Foil 
LIST OF TABLES

Page No.

TABLE 4-1 Transport and Blockage Test Results For 10 Inch Pipe Insulation Assembly

TABLE 4-2 Transport and Blockage Test Results For Stainless Steel Foil stock 
ACKNOWLEDGEMENTS

This study was sponsored by the U.S. Nuclear Regulatory Commission in relation to Unresolved Safety Issue A-43, "Containment Emergency Sump Performance." The leadership and dedication of Mr. Aleck Serkiz, NRC Task Manager, contributed much to the study.

The reflective metallic insulation assembly as well as the stainless steel foil material which were tested in this study were provided by Diamond Power specialty Company. This cooperation is gratefully acknowledged. 
In the event of a Loss of Coolant Accident (LOCA) in a nuclear power plant, it is possible that insulation material attached to pipes, steam generators, pumps, or other items in the containment building would be dislodged and damaged due to the impingement of the break jet. A concern with loose insulation material is its possible effect on the recirculation of water by the Emergency Core Cooling System (ECCS). To prevent debris from being entrained into the suction flow of the pumps, PWR sumps are enclosed by a trashrack and fine screen upon which insulation material could collect. Blockage of the racks and screens could cause a loss of head which could decrease the pump flowrate or possibly lead to insufficient available NPSH.

The buoyancy, transport and head loss characteristics of several fibrous insulations (mineral wool and fiberglass) have been previously investigated and the results have been reported in NUREG/CR-2982, Rev. 1, and in Reference 2. This study was designed to obtain similar data for reflective metallic insulation and materials of construction. The major findings can be summarized as follows:

I. Transport Velocities

a. Single sheets of thin stainless steel matexials (such as the 0.0025" 0.004 " thick foils used within reflective metallic insulation units) transported at relative low water velocities, $0.2-0.5 \mathrm{ft} / \mathrm{sec}$. This result is similar to the findings for fibrous insulation shreds. Single sheets of thicker foil $\left(0.008^{\prime \prime}\right)$ required higher velocities for transport, about 0.4 to $0.8 \mathrm{ft} / \mathrm{sec}$.

b. "As fabricated" reflective metallic insulation units required water velocities of $1.0 \mathrm{ft} / \mathrm{sec}$ or more for transport.

c. For all tested insulation material, txansport of the test specimen was much slower than the flow velocity.

d. When several pieces of foil were tested simultaneously and interacted before reaching the screen, the group of foils ceased movement at the low flow velocities which had sustained motion of the individual foil pieces. Higher velocities, up to $1.8 \mathrm{ft} / \mathrm{sec}$ were required to break up the group of foils and again initiate movement of individual foils.

\section{Transport and Blockage Modes}

a. Thin foils $\left(0.0025-0.004^{\prime \prime}\right.$ thick) transported in an intermittent folding and tumbling manner, whether originally crumpled or not. Depending on the position and shape of the foils just upstream from the screen, the foils would either flip onto the screen to their full area or be pressed onto the screen in a folded position. 
b. Rigid pieces of foil (either the thicker 0.008 " full size pieces or small sized thinner foil) tended to be transported by sliding along the bottom, requiring higher velocities for transport than the more flexible foil samples. The rigid pieces did not change geometry during transport, and were usually flipped onto the screen or retained their original crumpled shape. If the relatively rigid foils were larger than the water depth, folding onto the screen sometimes occurred.

c. Neither the flexible thin foils, nor the relatively stiffer foils, ever became "water borne." A portion of the foil was always in contact with the test flume floor. Therefore, the screen was never blocked beyond the foil width or length. Blockage up to the foil diagonal was never observed, but this may be because the water depth was generally less than the foil diagonal.

d. Total blockage of the screen did not occur even when the total foil area in a given test was somewhat more than twice the wetted screen area. The maximum screen blockage observed was $80 \%$. This factor is mainly due to the significant foil overlap that occurred in the screen blockage pattern. 


\subsection{INTRODUCTION}

In the event of a Loss of Coolant Accident (LOCA) in a nuclear power plant, it is possible that insulation material attached to pipes or other items in the containment building would be dislodged due to the impingement of the break jet. A concern with loose insulation material is its effect on the recirculation of water by the Emergency Core Cooling system (ECCS). To prevent debris from being entrained into the suction flow of the pumps, PWR sumps are enclosed by a trashrack and fine screen upon which insulation material could collect. Blockage of the racks and screens would cause a loss of head which could decrease the pump flowrate or possibly lead to insufficient available NPSH.

To furnish information on the conditions under which insulation debris would be transported to the sump screen and on the head loss which could result from screen blockage, the buoyancy, transport and head loss characteristics of several non-encapsulated fibrous insulation (mineral wool and fiberglass) were studied and reported in (1) and (2). The study described herein was aimed at providing similar information for reflective metallic insulation complementing the methodology for evaluation of insulation debris effects presented in (3). Specifically, this study investigated the transport characteristics of reflective metallic insulation assemblies and parts thereof as well as the resulting screen blockage modes.

In the transport part of the study, the flow velocities needed to initiate the motion of sunken pieces of insulation, either entire jackets or components thereof, either basically undamaged or crumpled, were determined. The effects of interactions with other pieces of insulation or flow boundaries were also observed and recorded.

The screen blockage modes, i.e. the ways in which pieces of reflective metallic insulation would collect on and block a vertical PWR sump screen, were qualitatively assessed. Points of basic interest were whether the insulation pieces would flip vertically against the screen or remain on the floor, whether they would be flattened against the screen or folded and, when many pieces were released, whether overlap would be prevalent or not. These observations were meant to be used as input to the development of a "screen blockage model" which would allow the determination of the head loss at the screen which would result from the accumulation thereon of a given amount of insulation. 


\subsection{METHODOJ,OGY}

\subsection{Insulation Components Tested}

The reflective metallic insulation pieces tested were either components of a 36 inch long insulation assembly for 10 inch pipe furnished by Diamond Power specialty Company or sheets of stainless steel foil of different thicknesses.

One of the units of the insulation assembly used in the tests is drawn schematically in Figure 1 and photos of the whole and partly dismantled assembly are presented in Figures 2 to 5. For the 10 inch pipe, the insulation assembly is made of two unit attached together by metal clasps, see Figures 2 and 4. Above a certain pipe diameter more than two units are needed as the peripheral length of individual units is typically less than 36 inches. Each unit is composed of an outer cover, an inner cover and end covers encapsulating a number of thin stainless steel foil sheets held in place by crimp separators, see Figures 3 and 5. The outer, inner and end covers are held together by spot welds but the inner foils, on which the crimp separators are spot welded, are not attached to each other or to the covers, see Figure 5. All the components of the insulation units are made of stainless steel of the following thicknesses:

$\begin{array}{lll}\text { Outer Cover } & : & 0.037 \text { inch } \\ \text { Inner Cover } & : & 0.015 \text { inch } \\ \text { Inner Foil } & : & 0.0025 \text { inch } \\ \text { Crimp Separators: } & 0.0025 \text { inch }\end{array}$

The damage modes of reflective insulation assemblies exposed to the high energy break jet which could occur during a LOCA are not easily determined and a range of conditions was therefore considered from undamaged assembly units to individual components of the units, undamaged or crumpled. Undamaged units would result if the fastening clasps failed first, releasing the jacket sections. Components of a unit could be released, if the break jet penetrated the section and, raising the inside pressure, burst the cover open. The uncovered face where sections of the same jacket abut (see Figure 3) is a zone where jet penetration could occur. Upon opening of the cover, the inner foils could be released as they are not attached to each other or to the covers. The degree of crumpling and amalgamation of the foils is difficult to predict and several modes were therefore considered in the experiments. Crushed but whole insulation units were not tested, but their transport velocity can be expected to be larger than that of undamaged units and these were considered in the tests.

In addition to the "as fabricated" insulation unit and components of it (separated by dxilling out the spot welds), pieces of stainless steel foil of $0.0015,0.0040$ and 0.0080 inch thicknesses were tested. The 0.0015 inch foil was considered because it was available and would provice additional information on thickness dependencies although such thin foil is not presently used in reflective metallic insulation. The 0.0040 and 0.0080 inch foils were 


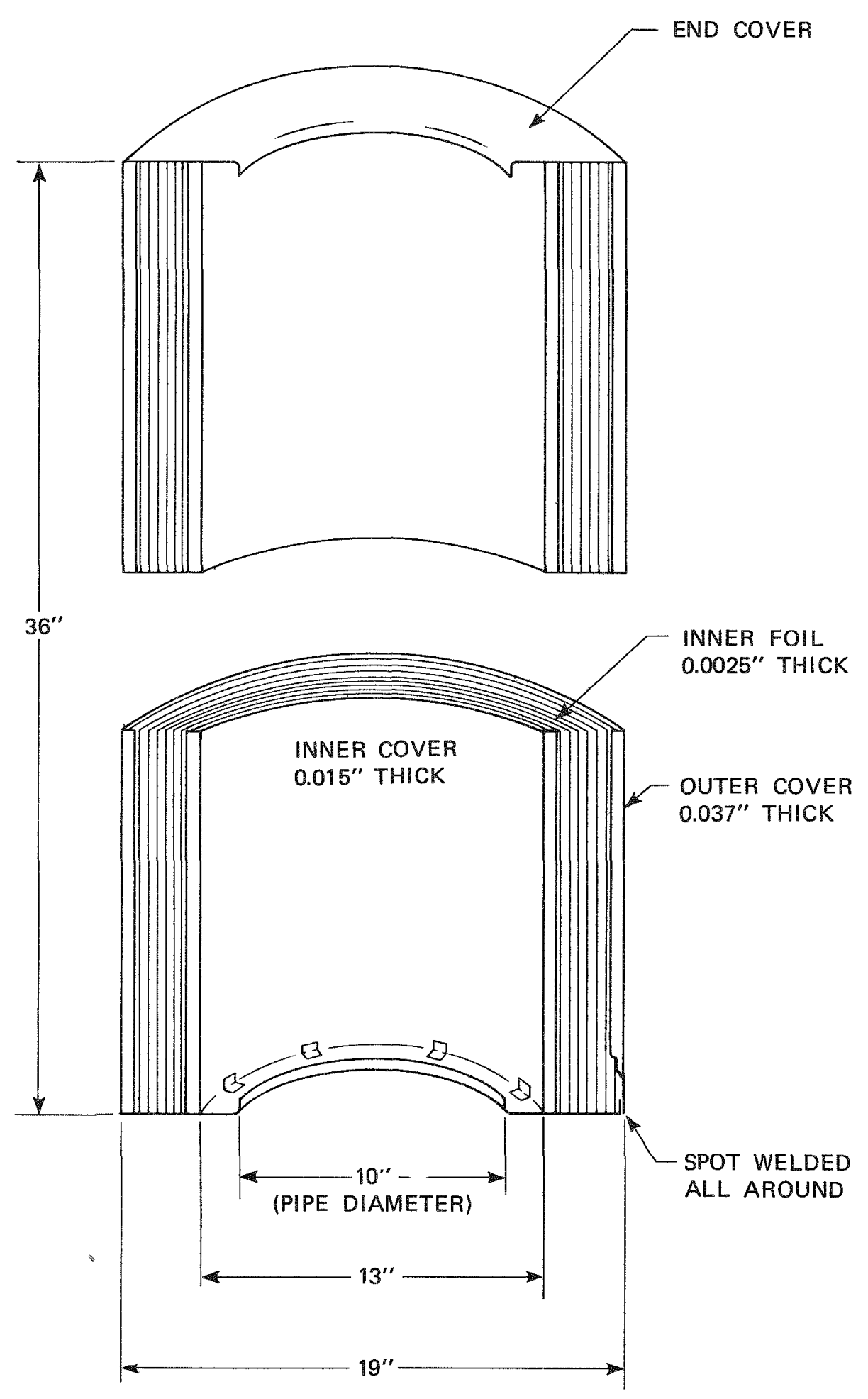

FIGURE 1 SCHEMATIC DRAWING OF REFLECTIVE METALLIC INSULATION UNIT FOR 10 INCH PIPE USED IN TESTS 


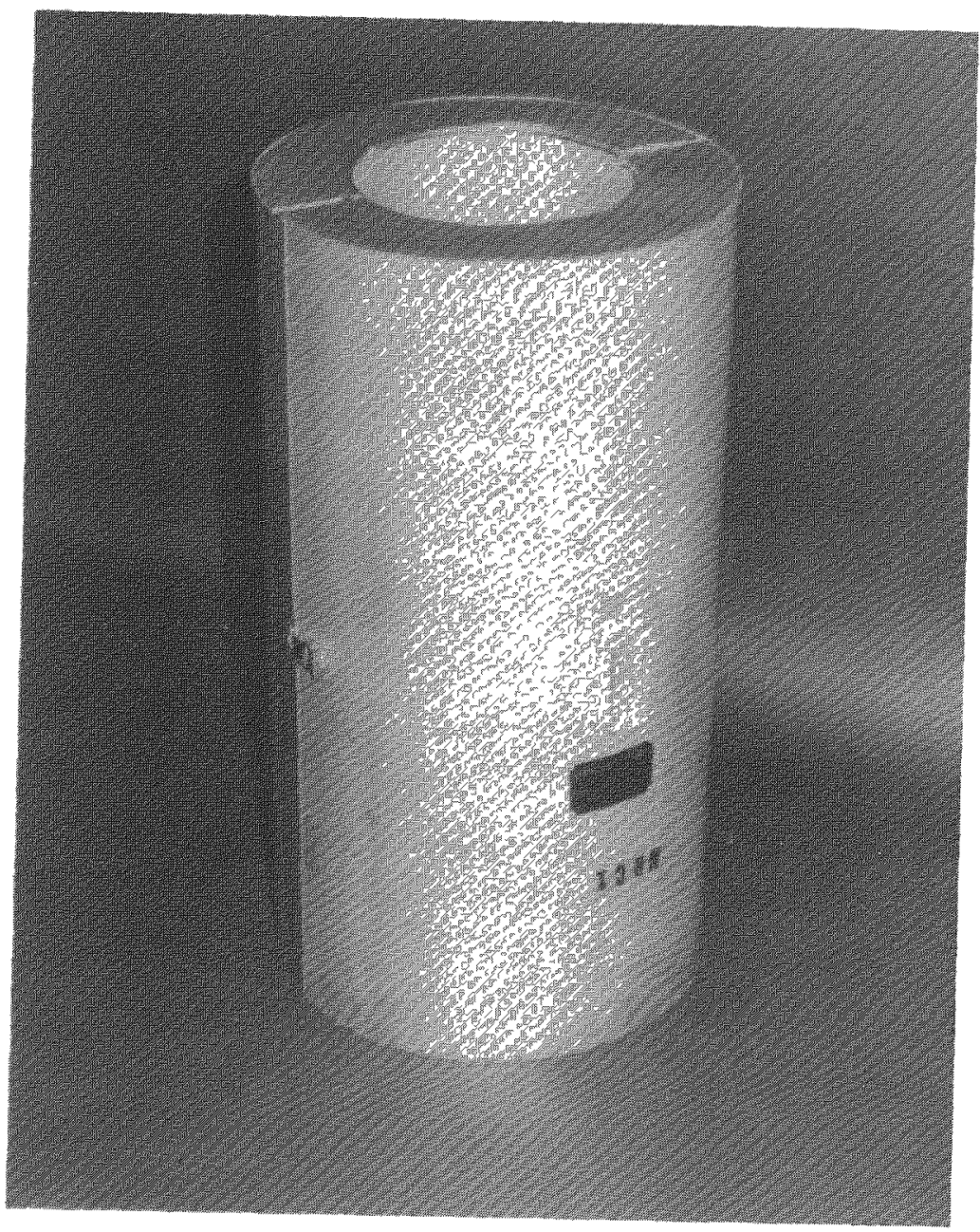

FIGURE 2 REFLECTIVE METALLIC INSULATION ASSEMBLY FOR 10" PIPE USED IN TESTS 


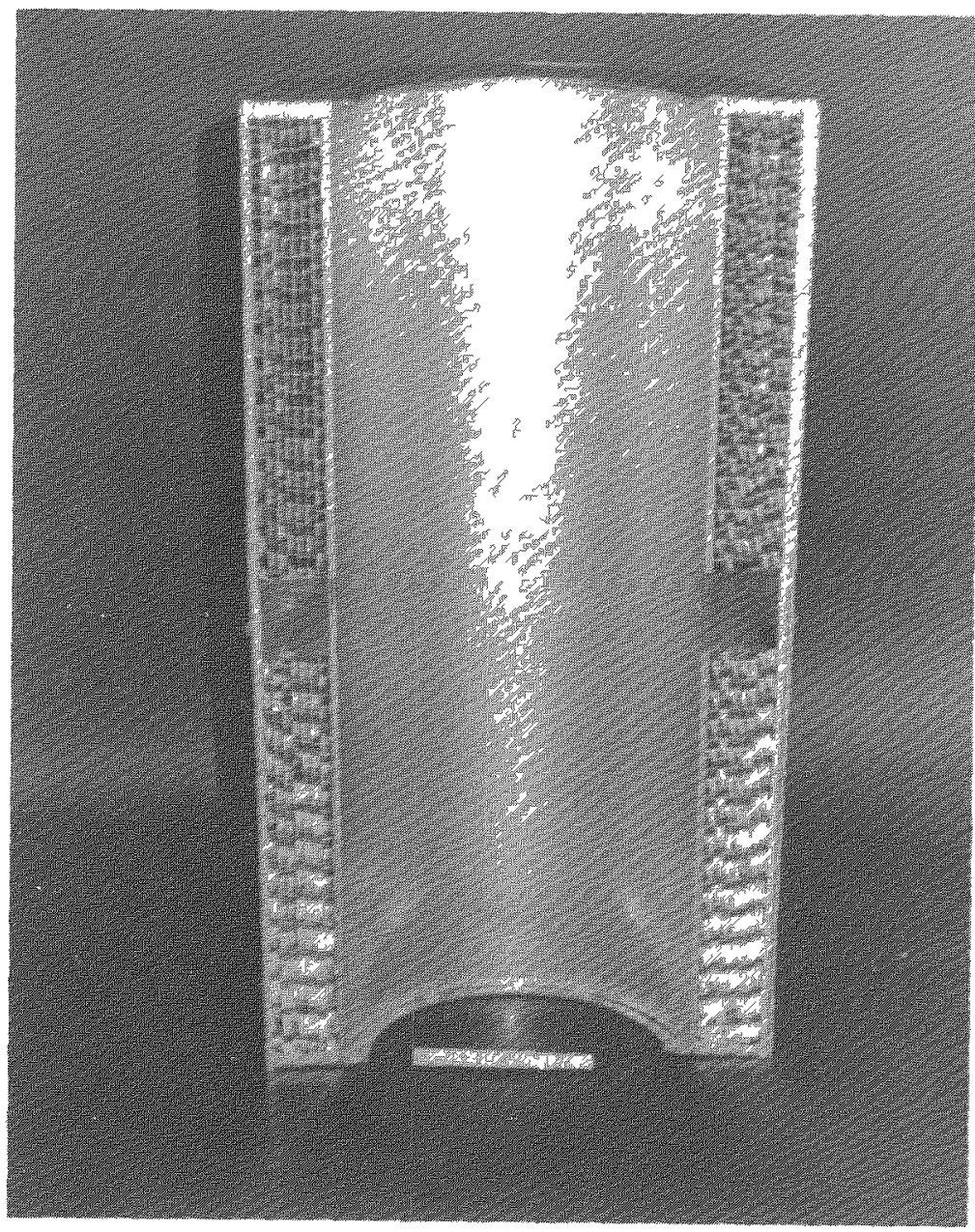

FIGURE 3 ONE OF THE TWO UNITS OF THE INSULATION ASSEMBLY TESTED 


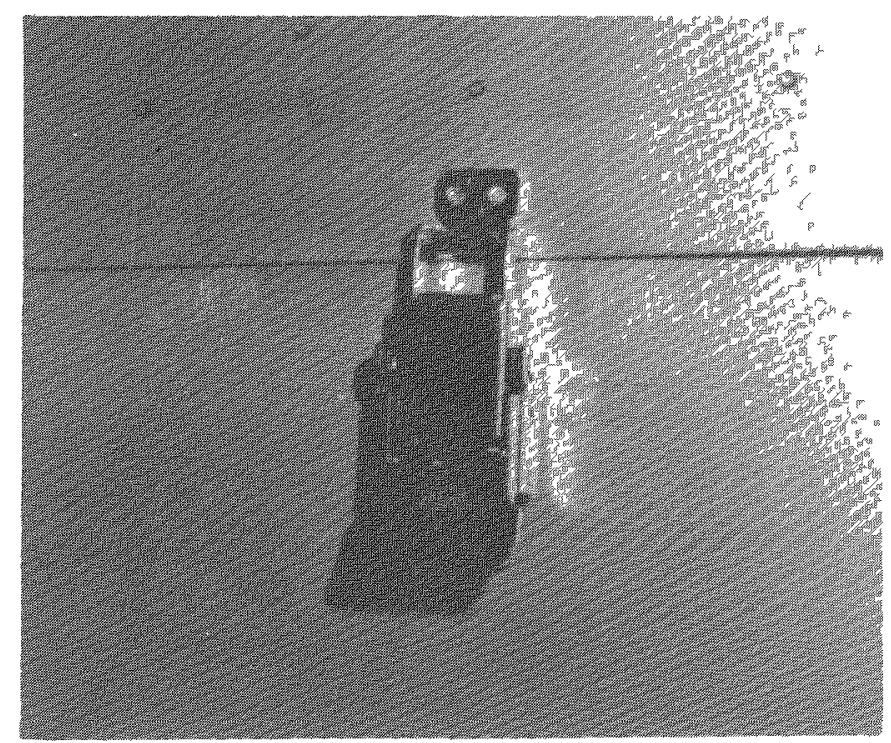

FIGURE 4 METAL CLASP ATTACHING UNITS OF REFLECTIVE METALLIC INSULATION

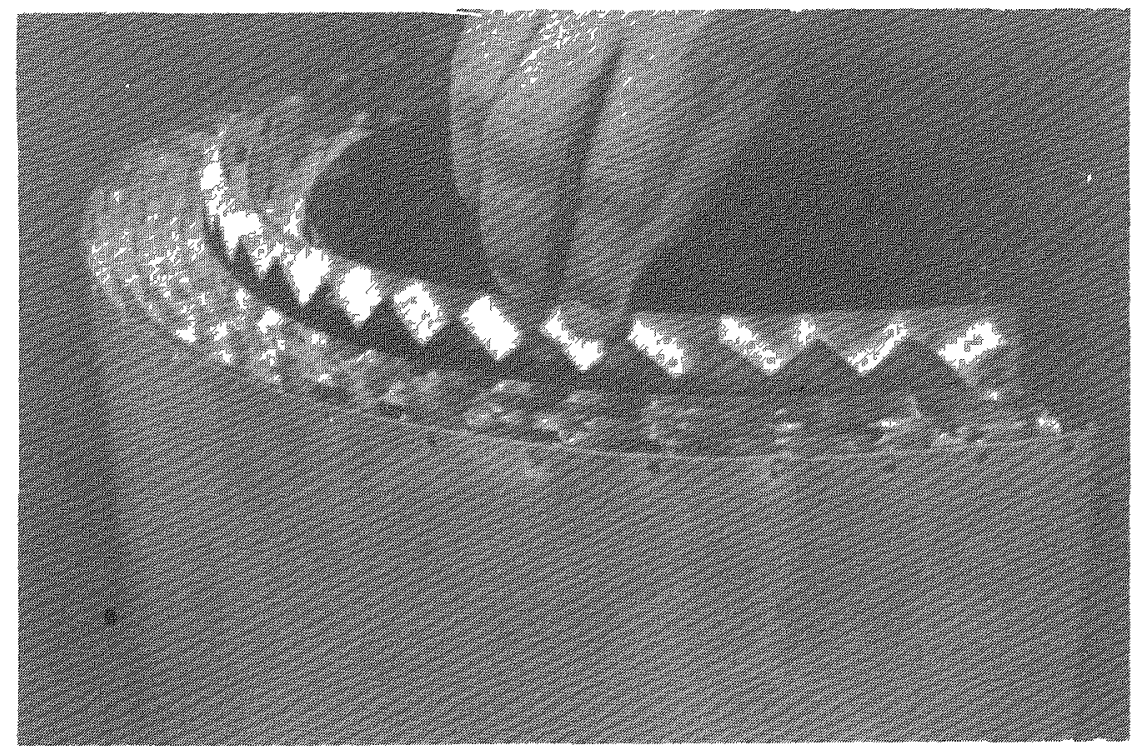

FIGURE 5 INSULATION UNIT WITH END COVER REMOVED (NOTE DRILLED OUT SPOT WELDS) AND INNER FOIL BEING PULLED OUT (NOTE CRIMP SEPARATOR) 
considered because much of the previously installed reflective metallic insulation in nuclear plants contain foils of these thicknesses.

\subsection{Test Facility and Instrumentation}

The transport and screen blockage tests were conducted in a metal flume $6 \mathrm{ft}$ wide by $6 \mathrm{ft}$ deep and approximately $40 \mathrm{ft}$ long. As shown schematically in Figure 6, water was introduced in the flume through a perforated plate, to yield a uniform velocity distribution. This uniformity was verified by measuring vertical and horizontal velocity profiles approximately 13 ft from the perforated plate. Further downstream the profiles become less uniform with boundary layers developing along the bottom and side walls.

At the downstream end of the flume a screen and trashrack similar to those used around recirculating sumps were erected vertically across the full width. The screen was made of $1 / 16$ inch wire with a $1 / 4$ inch mesh directly behind a standard 1 inch floor grating trashrack with its more closely spaced bars oriented horizontally. A photo of the flume showing the screen and trashrack is given in Figure 7 .

The flow velocity in the flume was measured using a calibrated laboratory current meter of the propeller type located $13 \mathrm{ft}$ downstream of the perforated plate (where the velocity profile was measured to be approximately uniform), on the flume centerline and approximately 4 inches above the bottom.

\subsection{Testing Procedure}

For all the tests, sections of reflective metallic insulation or components thereof were deposited in the flume approximately 20 ft upstream of the trashrack and screen, or $2 \mathrm{ft}$ downstream of the velocity meter. The flow velocity was then gradually increased and the velocity at which the sample(s) started to move was recorded. The motion of the sample(s) was observed and recorded, photographically if warranted. If the sample stopped and judgement was passed that it would probably not move further in these conditions, the velocity was increased until further movement was observed. This procedure was pursued until the sample(s) reached the screen. The manner in which the sample(s) collected on the screen was recorded, photographically if warranted.

The following samples from reflective metallic insulation were considered in the tests:

i) From the $10^{\prime \prime}$ pipe insulation assembly described in 2-1:

- undamaged assembly unit (half of entire assembly)

- outer cover

- inner cover

- end covers

- inner foils

- single sheet uncrumpled with and without separator crimp 


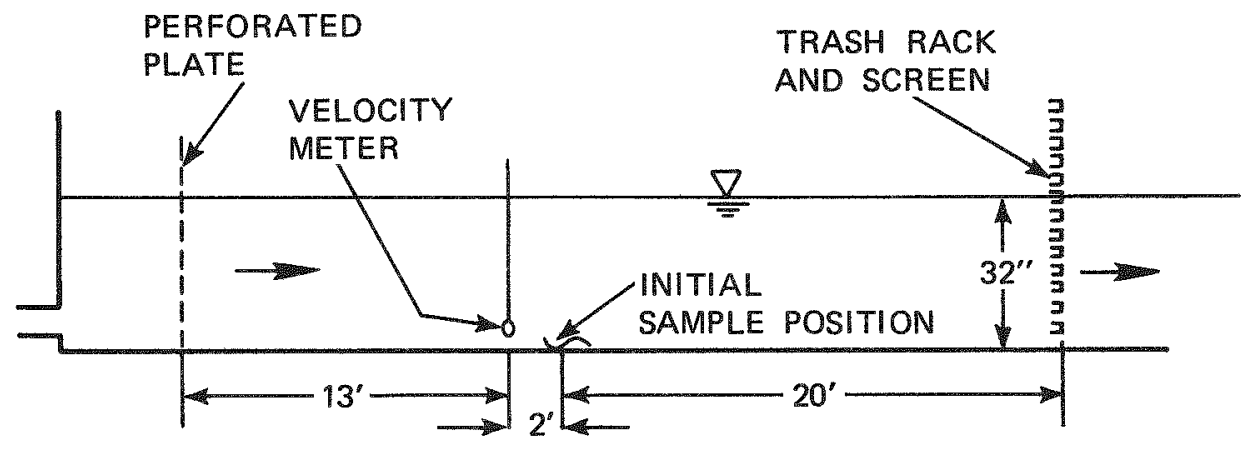

FIGURE 6 SCHEMATIC OF TEST FACILITY

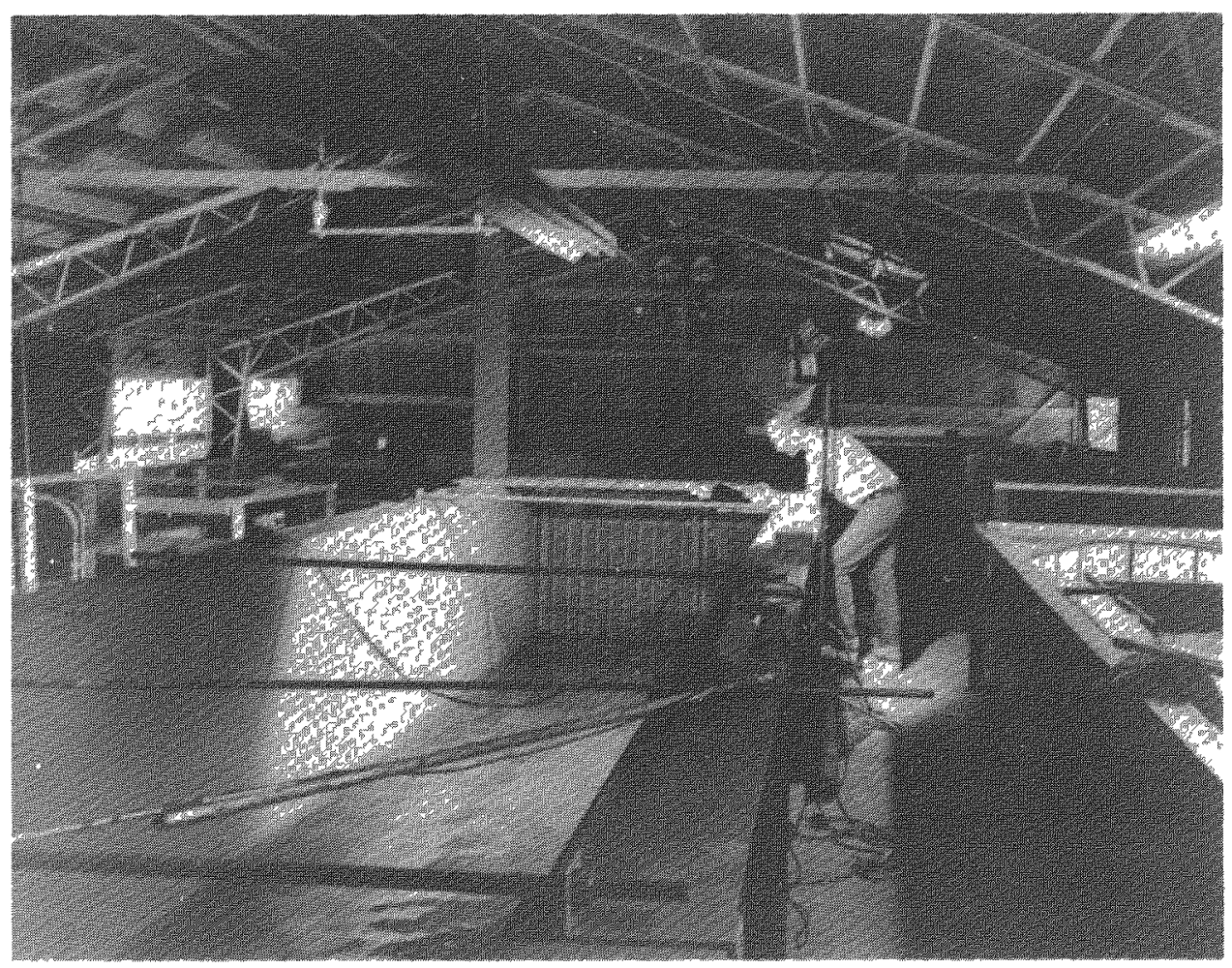

FIGURE 7 PHOTO OF TEST FACILITY LOOKING DOWNSTREAM 
- single sheet crumpled in various manners, with and without separator crimp.

- several whole sheets crumpled and uncrumpled

- single cut-up sheet measuring $24 " \times 21 "$, crumpled and uncrumpled

- several cut-up sheets measuring 8" $x$ 8", crumpled and uncrumpled

- several cut-up sheets measuring $3^{\prime \prime} \times 3^{\prime \prime}$, crumpled and uncrumpled

- separator crimp stock

ii) From flat stock

- 0.0015 inch foil approximately $12^{\prime \prime} \times 12^{\prime \prime}$, crumpled and uncrumpled

- 0.0040 inch foil approximately $36^{\prime \prime} \mathrm{x} 36^{\prime \prime}$, crumpled and uncrumpled, single and multiple sheets

- 0.0080 inch foil approximately $36^{\prime \prime} \times 36^{\prime \prime}$, crumpled and uncrumpled, single and multiple sheets

In all the transport tests, except one, the water depth was kept at 32 inches. This depth is representative of the minimum water depths typical for the recirculation mode of a LOCA and it is the same as that used for the tests reported in (1). The use of a single cepth is a limitation of this study, as depth could affect transport and blockage, particularly through the depth to sample size ratio. One test was performed with a water depth of 60 inches to establish whether "water borne" or suspended transport of foils could occur under large water depths.

All the tests were performed three or four times since variability could be expected in the results due to many small differences between the test conditions, such as the initial placement of the samples or the turbulence of the flow. The results presented in section 4.0 are averages of the individual test results emphasizing the worst case. If clear variations were obtained between repeat tests, those are noted. 


\subsection{SUMMARY OF KEY FINDINGS}

\subsection{Transport Velocities}

a) Single sheets of thin stainless steel foil used in reflective metallic insulation $(0.0025$ and 0.0040 inch thick) can be transported by water flow velocities as low as 0.2 to $0.5 \mathrm{ft} / \mathrm{sec}$. Single sheets of thicker foil $(0.008$ inch) required higher velocities for transport, about 0.4 to 0.8 $\mathrm{ft} / \mathrm{sec}$.

b) Crumpled foils tend to transport at lower velocities than uncrumpled foils.

c) Transport velocity tends to increase with material thickness, except for easily flexible foils where the thickness dependence is smaller.

d) In all cases the velocity of motion of the sample is much lower than that of the flow.

\subsection{Transport Modes}

a) Transport at the lower velocities occurs when the foil sheet is flexible enough that a corner or edge can be bent up by the flow thereby increasing the frontal area and therefore the drag. The resulting motion is one of intermittent folding, tumbling and rolling.

b) Rigid pieces tend to be transported by sliding along the bottom. Rigidity can result from greater thickness $(0.008$ inch and above) or small size (less than about 12 inch by 12 inch for 0.0025 inch foil). Higher flow velocities are typically needed for transport of rigid pieces than for transport of flexible pieces.

c) Even with high flow velocities (about $2 \mathrm{ft} / \mathrm{sec}$ ) and large water depths (60 inches but velocity only $1.6 \mathrm{ft} / \mathrm{sec}$ ) the samples were never observed to become "water borne," i.e. to loose contact with the bottom.

d) The vertical side walls of the test flume were observed to hindex the transport of samples. Samples entering in contact with a wall were often pushed and folded against it, needing higher flow velocities to be dislodged.

e) When several pieces of foil were released simultaneously, their interaction during the transport process often caused jamming and immobilization of the pieces. High flow velocities, up to $1.8 \mathrm{ft} / \mathrm{sec}$, were then required to break up the jams and resume the transport. 


\subsection{Blockage Modes}

a) Most foils readily flip vertically against the screen upon arriving there. Whether originally crumpled or not, the foils become flattened against the screen by the water force except the thicker foils $(0.008$ inch) which remain crumpled. The more flexible foils often become folded on the screen, blocking less than their surface area. The large 0.0080 inch thick foils which exhibited rigidity relative to their transport mode (see 3.2.b) but whose dimensions were larger than the water depth often folded on the screen, a portion being caught under the trashrack.

b) Because insulation specimens never became "water borne," they never blocked the screen above their width or length. Blockage up to the diagonal height was never observed but this may be due to the fact that the water depth was less than that height (see 3.4.a).

c) When several foil pieces were released simultaneously, significant overlap was observed on the screen so that even if the total foil area was larger than the screen area ( 1.6 to 2.2 times), the screen was never fully blocked (only up to about $80 \%$ of area blocked).

\subsection{Iimitations}

a) All the tests (except one for "water borne" transport mode checking) were done with a water depth of 32 inches. This depth was used to allow comparison with earlier studies, however, it could have an effect on the blockage modes, as it was smallex than the typical foil length (36 inches) and diagonals.

b) The flume width was only $6 \mathrm{ft}$, compared to usually longer sump screens and side wall effects could be present in the observed blockage modes. Since the side walls were observed to hinder transport, (see 3.2.d) screen sections near the walls could have a reduced probability of becoming blocked. 


\subsection{RESULTS}

The results of all the tests are summarized in Tables 4-1 and 4-2 for the 10 inch pipe insulation jacket and the stainless steel foil stock. These tables provide the measured flow velocities needed to initiate the motion of the sample as well as the velocities needed to transport the sample to the screen. The distinction is made between these two velocities because it was not infrequent that samples would move at a certain flow velocity but not go all the way to the screen, which required a higher velocity. This was particularly true when the sample was made up of several pieces which would often jam, requiring a high flow velocity to unjam. In these cases, the velocity indicated in the table for transport to the screen is the velocity needed to transport all the pieces to the screen. Since the insulation pieces typically flipped against the screen as soon as they reached it, a velocity to flip the sample is not indicated.

The tables of results also contain comments on the transport and screen blockage modes. Further description of the results is provided in the text below.

\subsection{Results for the 10 Inch Pipe Insulation Assembly}

\subsubsection{Undamaged Assembly Unit (Half of Entire Assembly)}

Since an assembly unit is basically an enclosure containing much empty space the possibility of its floating was first tested. For that, the unit was placed on the water surface with its concave side up and a sinking time of three to four minutes was measured. The same test was performed for an assembly unit with one of its end covers removed and a sinking time of about one minute was obtained. These times are less than the typical time after the beginning of a LOCA when the recirculation system is activated (approximately 20 minutes) so that transport of insulation units to the sump screen by floatation is not likely. Upon sinking, the units either stood up on end or laid flat on the bottom. These tests were performed in stagnant water.

The flow velocity needed to topple undamaged units standing vertically on end was measured to vary from $0.2 \mathrm{ft} / \mathrm{sec}$ if the concave side faced the flow, to $0.9 \mathrm{ft} / \mathrm{sec}$ if the convex side faced the flow.

Undamaged units lying on the bottom with their concave side up were transported to the screen at a flow velocity of approximately $1.0 \mathrm{ft} / \mathrm{sec}$. The transport started at this velocity regardless of the initial orientation of the sample to the flow direction. If the sample was initially almost parallel to the flow direction, it first reoriented itself abruptly perpendicular to the flow (at about $1.0 \mathrm{ft} / \mathrm{sec}$ ). The transport mode was one in which one end of the unit would move toward the screen, then stop, then the other would move, etc. This alternating motion, once initiated, continued until the unit reached the screen. There, the unit would either flip against the screen (see 
Figure 8-a and 9) or remain stuck in a partially flipped position (Figure 8-b). In either case the screen blockage is minimum unless the ends of a fully flipped section would become blocked by other debris.

Undamaged insulation units Iying on the bottom with their concave side down did not move at the maximum flume flow velocity of about $2.0 \mathrm{ft} / \mathrm{sec}$.

\subsubsection{Outer Cover (0.037 Inch Thick, 19 Inches Diameter)}

When lying on the bottom with their concave side up, the outer covers of the insulation units started to move at a flow velocity of approximately 0.7 $\mathrm{ft} / \mathrm{sec}$ and moved continuously to the screen at a flow velocity of approximately $0.8 \mathrm{ft} / \mathrm{sec}$. Upon reaching the screen the covers (which are rigid enough to retain their half cylinder shape) either flipped up against the screen or became stuck in a half flipped position, very similaxly to the whole jacket sections (see 4.1.1).

When lying with their concave side down, the outer covers did not move at a flow velocity of $1.8 \mathrm{ft} / \mathrm{sec}$.

\subsubsection{Inner Covers (0.015 Inch Thick, 13 Inches Diameter)}

When lying with their concave side up, the inner covers moved at a flow velocity of approximately $0.7 \mathrm{ft} / \mathrm{sec}$ and reached the screen at a flow velocity of approximately $0.8 \mathrm{ft} / \mathrm{sec}$. With the covers lying concave side down these velocities were respectively 1.1 and $1.6 \mathrm{ft} / \mathrm{sec}$.

When reaching the screen the inner covers generally flipped against the screen and became completely flattened against it by the force of the flow. This is in contrast to the outer covers which, being thicker, kept their shape. The inner covers, therefore, block an area of the screen equal to their surface area (no folding of the cover was ever observed).

\subsubsection{End Covers}

The end covers never moved, even at the highest flume flow velocity of approximately $2 \mathrm{ft} / \mathrm{sec}$.

\subsubsection{Inner Foil (0.0025 Inch Thick, 36 Inches by 25 Inches Average)}

a) Single sheets of uncrumpled inner foil were obsexved to start moving at approximately $0.35 \mathrm{ft} / \mathrm{sec}$ but they generally needed a flow velocity of about $0.5 \mathrm{ft} / \mathrm{sec}$ to move continuously and reach the screen. The mode of transport was one in which a corner or side of a foil sheet became lifted up by the flow, thereby increasing the frontal area, and therefore the drag, enough to initiate motion; see Figure 10. The 0.0025 inch thick foil is flexible enough that, during transport, the sheet continuously folded over itself, progressing in a rolling or tumbling mode. The transport velocity, however, and as could be expected, was much slower than the flow velocity. The presence or absence 


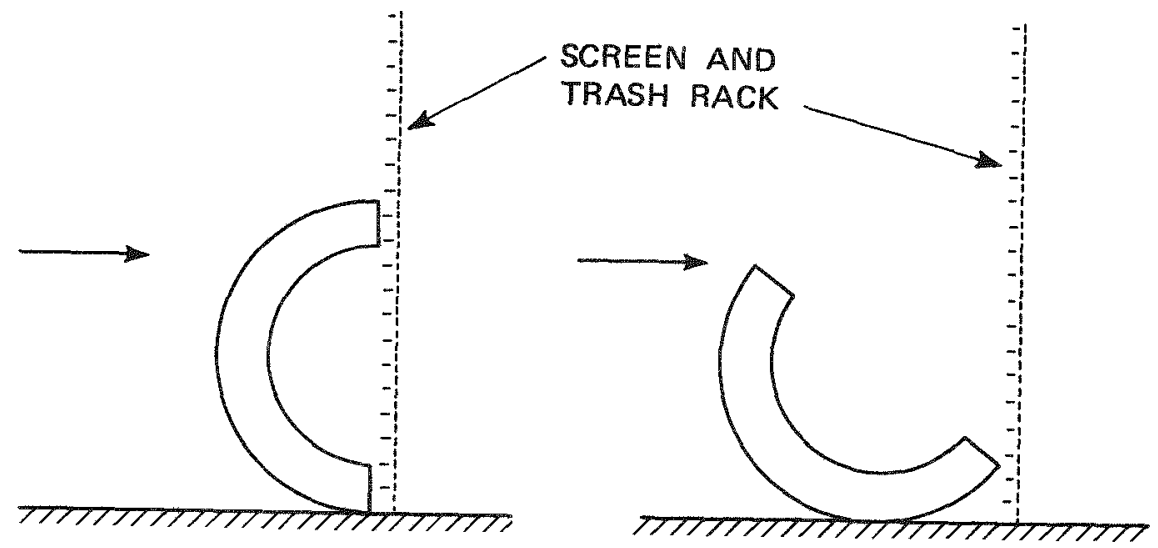
(a) FLIPPED
(b) PARTIALLY FLIPPED

FIGURE 8 POSSIBLE POSITIONS OF UNDAMAGED INSULATION UNIT (HALF OF ENTIRE ASSEMBLY) AGAINST SCREEN

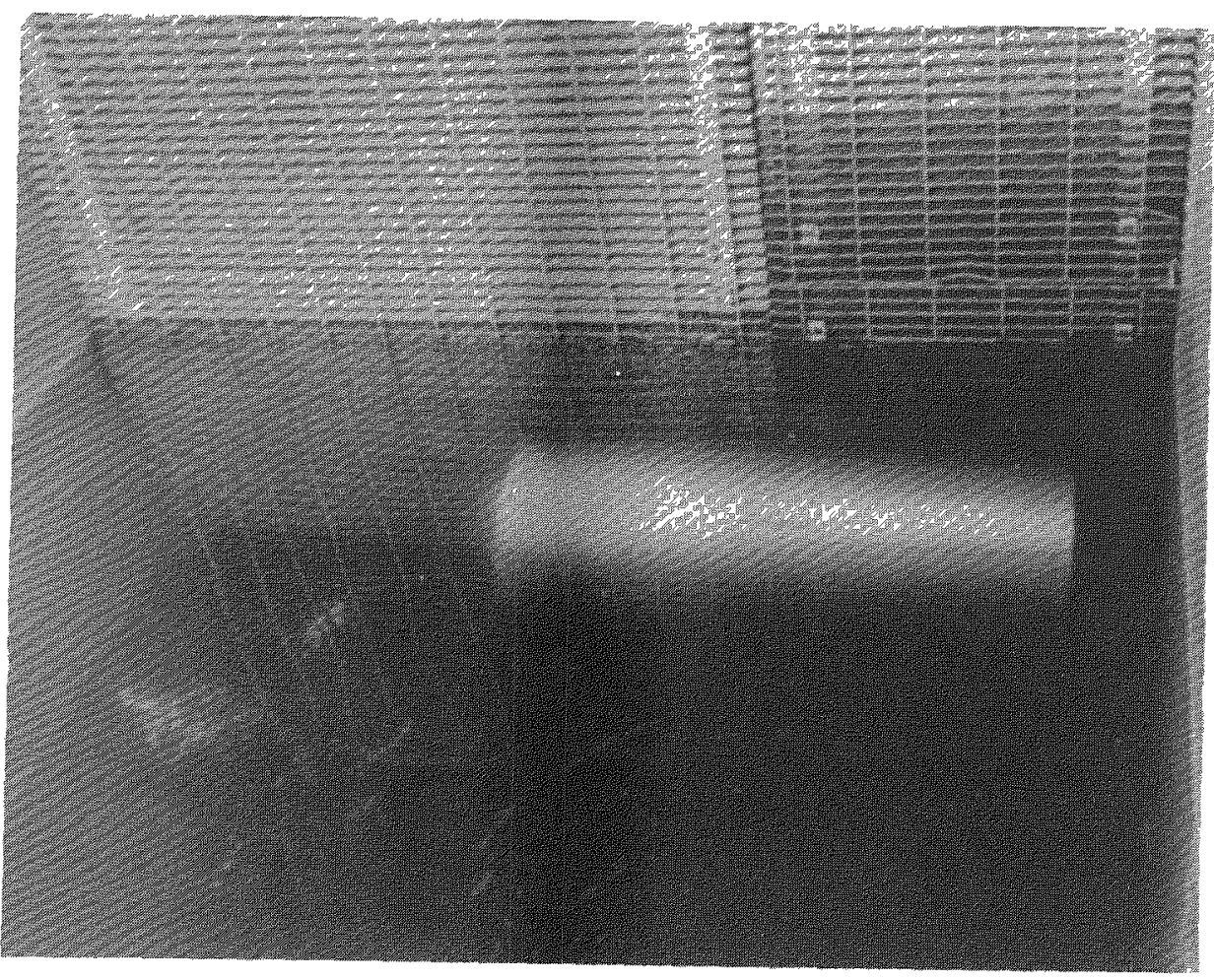

FIGURE 9 INSULATION UNIT (HALF OF ENTIRE ASSEMBLY) FLIPPED AGAINST SCREEN 

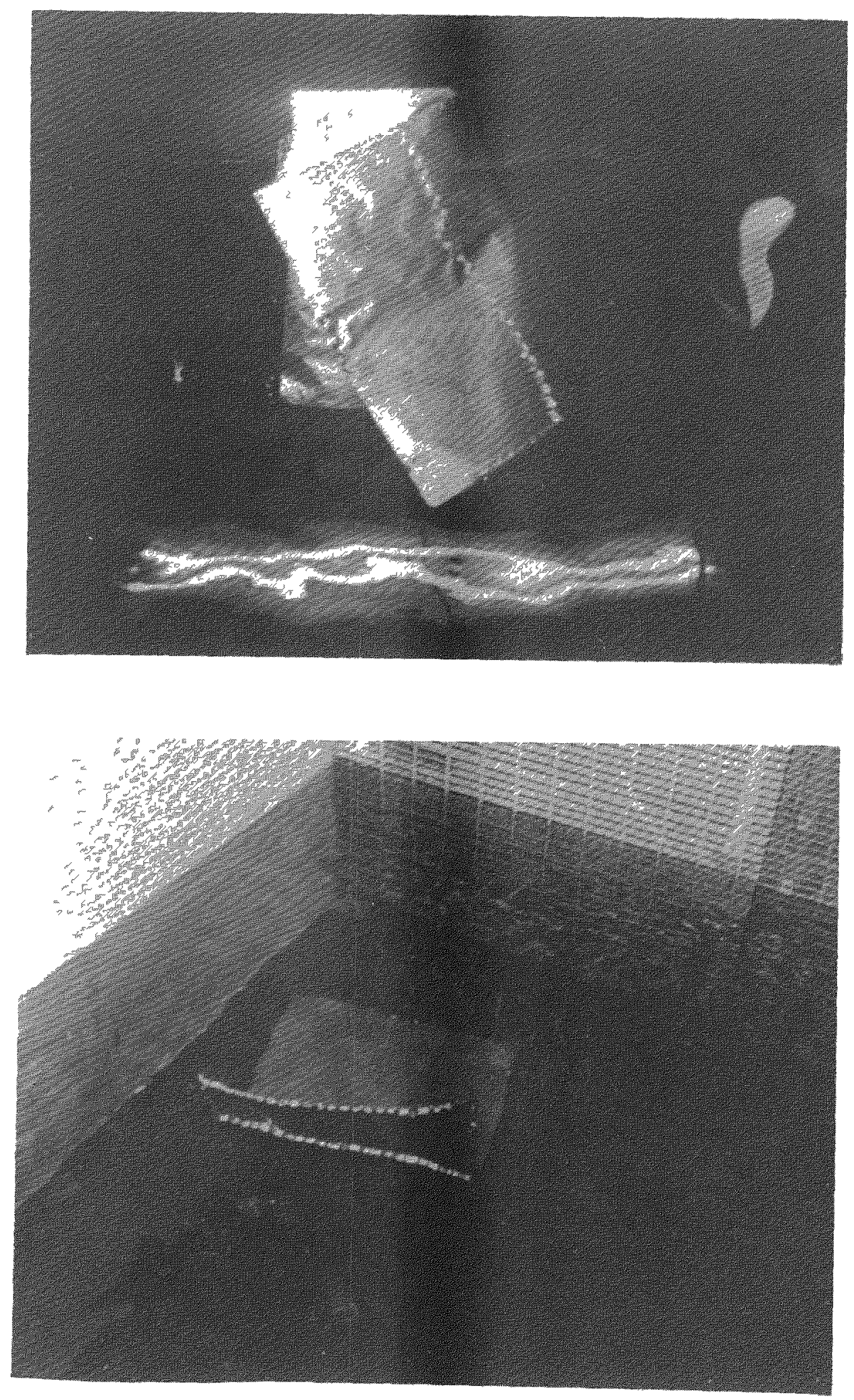

FIGURE 10 UNCRUMPLED INNER FOIL 10.0025 INCH THICKNESS) BEING BENT AND FOLDED BY THE FLOW DURING TRANSPORT 
of the separating crimp (which would probably remain at least partially attached to the foil in a LOCA, because of the numerous spot welds) was not observed to have a significant effect on the transport mode or velocities. Interaction with the side walls of the flume tended to hinder the transport of foil, as pieces, when coming in contact with the wall, would sometimes fold in such a way that the force of the flow would tend to push them against the wall and immobilize them. This is shown in Figure 13, for a crumpled foil. A higher flow velocity was then needed for transport to resume.

Upon reaching the screen, the foil sheets immediately flipped against it, this flipping being often part of the tumbling motion. Once against the screen, the foil was flattened by the flow force but the foil was often folded so that the blocked area was less than the total foil surface area. Photos of 0.0025 inch foils folded against the screen are presented in Figure 11. In a rare case the foil was practically unfolded on the screen.

In view of the "tumbling" mode of transport observed, the possibility for the foils to become "water borne," i.e. become suspended in the flow, was investigated by running experiments with high flow velocities, up to about 2 $\mathrm{ft} / \mathrm{sec}$. In all cases the foils were observed to always remain in contact with the bottom. Because of a concern that this result might be dependent on the water depth (which was 32 inches and therefore less than the 36 inches length of the foils), these tests were repeated with a water depth of 60 inches. With this depth, the maximum flow velocity which could be obtained in the flume was $1.6 \mathrm{ft} / \mathrm{sec}$. At this speed, foils were, again, not observed to become water borne. As a result of this transport characteristic, foils did not block the screen above their maximum dimension. This maximum dimension could be as much as the diagonal of the foils (44 inches) but, such a situation was not observed, perhaps because, in most of the tests, the water depth was only 32 inches.

b) Single sheets of crumpled inner foil are shown in Figure 12. The two photos in this figure show examples of the types of crumpling used in the tests; crumpling modes in which the foil would be compacted into a ball were not considered as they were considered unlikely outcomes of a LOCA. In the samples tested, the height of the foils after crumpling varied from approximately 3 to 8 inches. The flow velocity needed to initiate the motion of crumpled inner foils was approximately $0.20 \mathrm{ft} / \mathrm{sec}$ and a flow velocity of 0.25 $\mathrm{ft} / \mathrm{sec}$ was sufficient to produce continuous motion up to the screen. These transport velocities were somewhat dependent on the crumpling, with lower velocities (those given) obtained for larger crumpled foil heights. The mode of transport was similar to that described for the uncrumpled foils except that some modes of crumpling tended to confer added rigidity to the foils and, as a result, folding by the flow was less prevalent. In some cases the crumpled foils simply slid along the bottom. As for the uncrumpled foils, interaction with the flume side walls tended to hinder the transport; Figure 13 shows a crumpled foil arrested against the wall. 

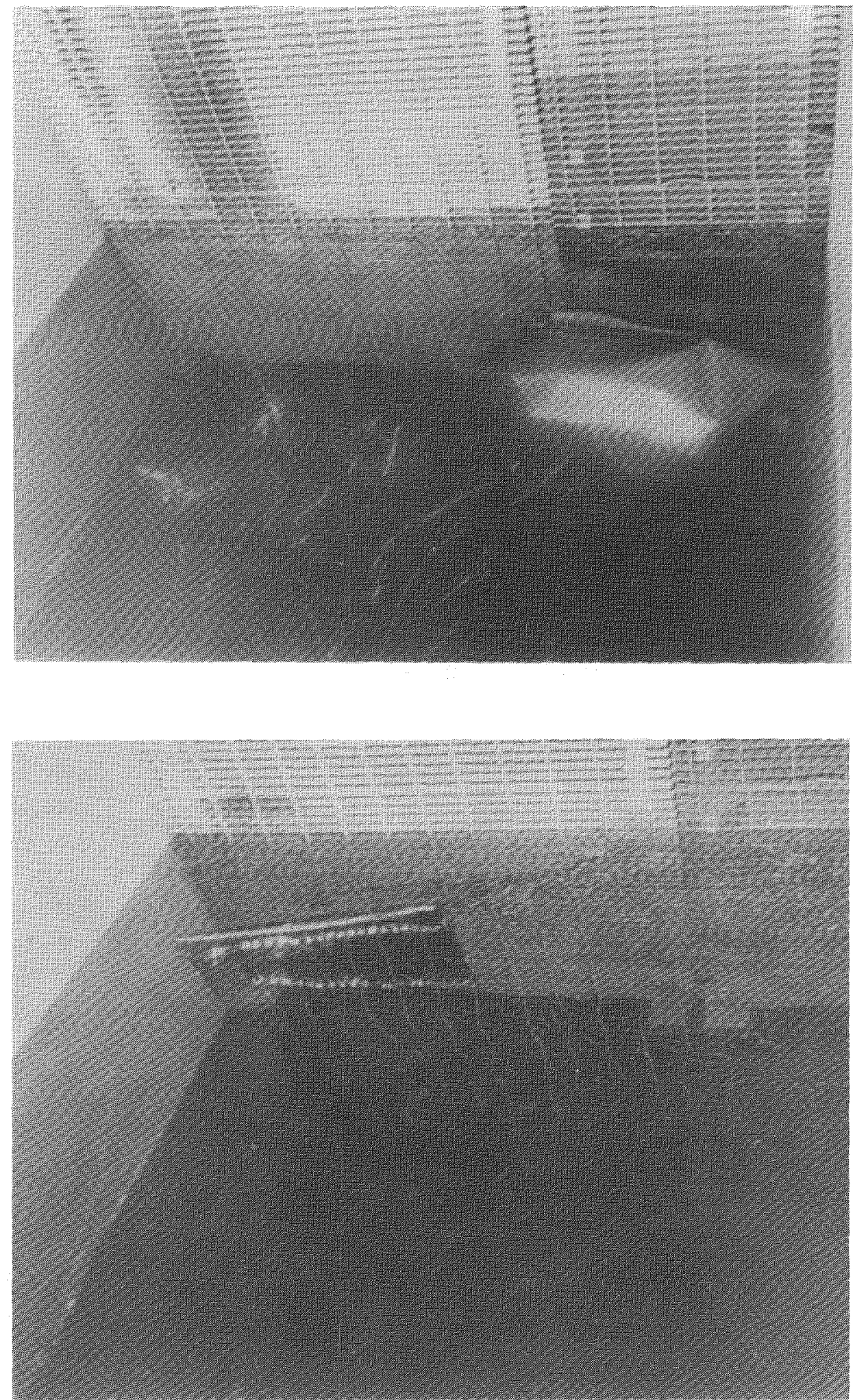

FIGURE 11 UNCRUMPLED INNER FOIL (0.0025 INCH THICKNESS) AGAINST THE SCREEN 

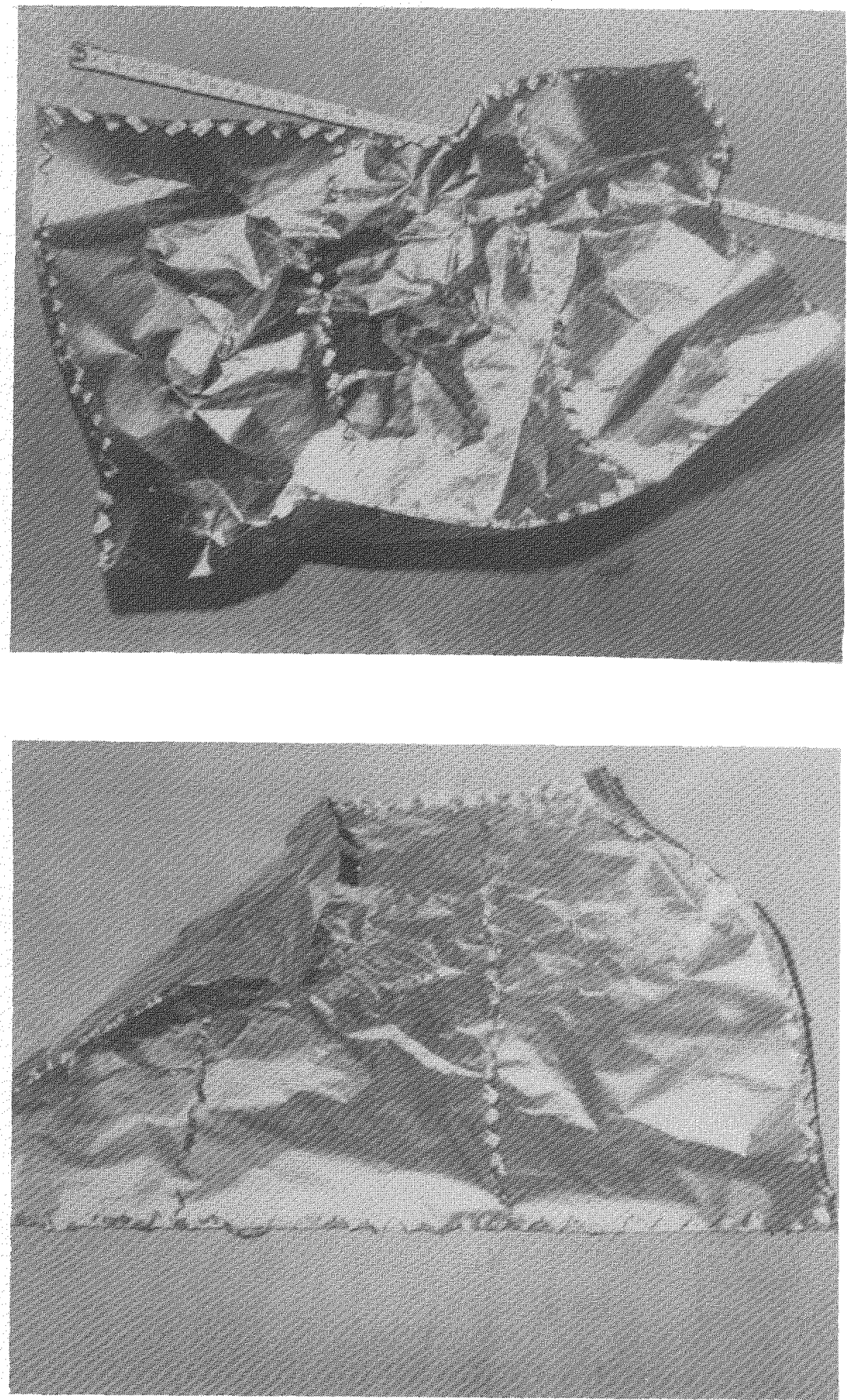

FIGURE 12 CRUMPLED INNER FOILS 10.0025 INCH THICKNESS) PRIOR TO TESTING 


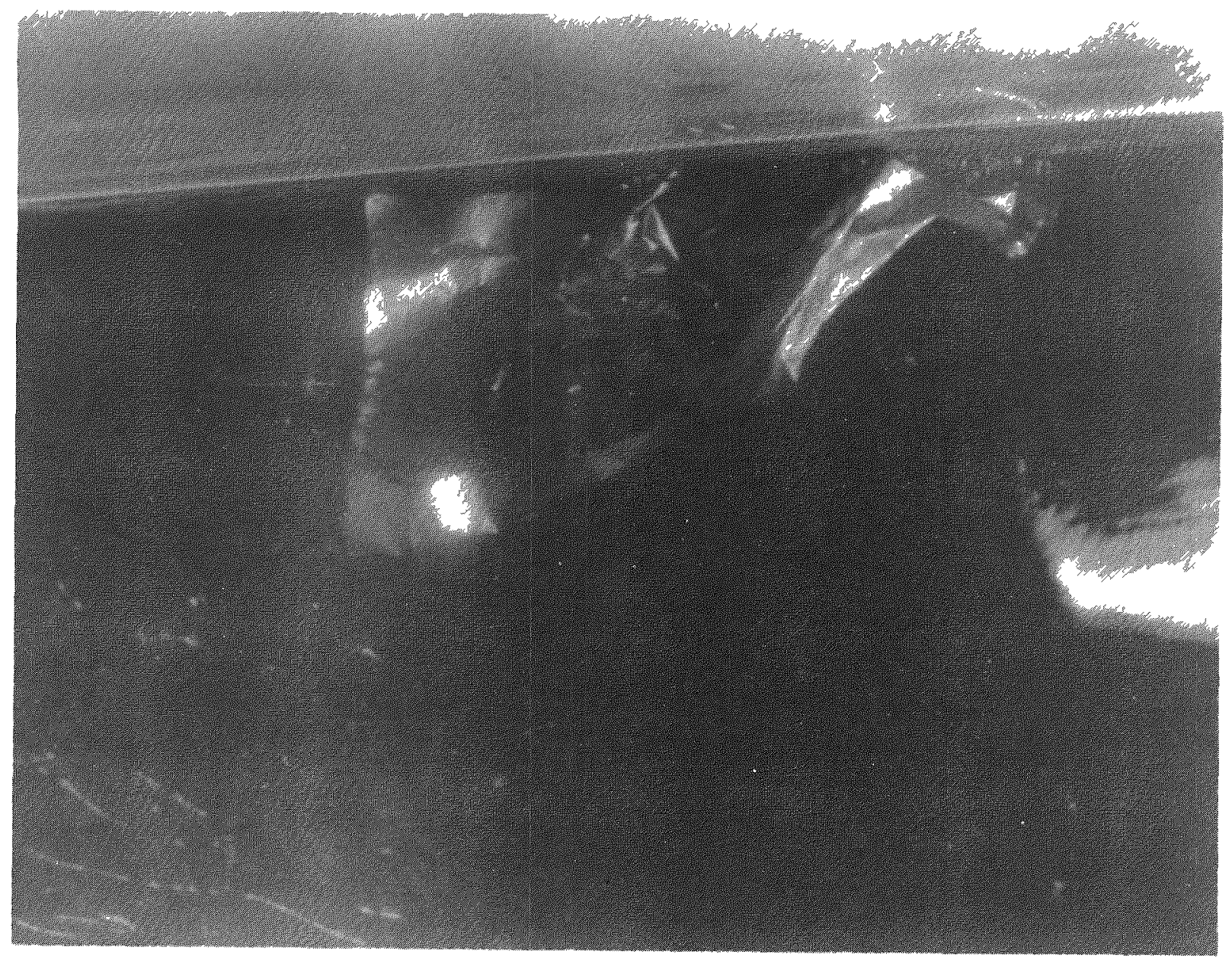

FIGURE 13 CRUMPLED INNER FOIL $(0.0025$ INCH THICKNESS) ARRESTED AGAINST THE FLUME SIDE WALL 
Upon reaching the screen, the crumpled foils flipped against it and tended to become flattened, and thereby somewhat uncrumpled, by the flow. Depending on the mode of crumpling and on the position of the foil upon arrival at the screen, the foils were or were not folded on the screen. As for the uncrumpled foils, water borne transport was not observed and blockage above the samples largest dimension did not occur.

c) When multiple sheets of inner foil (4 and 5), crumpled and uncrumpled were placed together (but generally not in contact with each other) in the flume, the initiation of motion occurred at the flow velocities noted above for single sheets and the mode of transport, with folding and tumbling of individual sheets, was similar: see Figure 14. Interaction of the individual foils, however, tended to create jams in which foils would interlock and stop moving: see Figure 15. A high flow velocity, up to $1.8 \mathrm{ft} / \mathrm{sec}$, was then needed to dislodge the jam and for transport to the screen to resume.

When reaching the screen, the foils flipped against it with considerable overlapping, see Figure 16, some of the foils being folded. The four and five foils used in the different experiments which wexe run have a total area equal to respectively 1.6 and 2.0 times the screen area, but only about $60 \%$ to $70 \%$ of the screen ever got blocked (Figure 16, bottom photo). A corresponding head loss, $\Delta \mathrm{H}$, of $0.7 \mathrm{ft}$ of water was measured at an approach velocity $\mathrm{V}$ of $0.7 \mathrm{ft} / \mathrm{sec}$, giving a loss coefficient $\Delta H / \mathrm{V}^{2} / 2 \mathrm{~g}=92$. It is possible that the presence of the side walls had an effect on this blockage mode, as foils blocking screen sections near the walls were affected by the wall.

d) Cut-up sheets of inner foil (0.0025 inch thickness) were also considered, representing foils from smaller pipe insulation jackets. Pieces measuring 24 x 21 inches, 8 x 8 inches and $3 \times 3$ inches were considered, crumpled and uncrumpled. The velocities to initiate motion and to bring all the samples to the wall are listed in Table 4-1. The observations to be made are that smaller pieces need larger velocities to be transported, exhibiting more rigidity and a sliding rather than folding and tumbling transport mode. The $24 \times 21$ inch pieces did fold and tumble but not the smaller ones which slid along the bottom with their upstream edge sometimes slightly lifted, thereby increasing their frontal area and reducing the area of contact with the bottom. Crumpled pieces transported at the same or lower velocities than uncrumpled pieces. Upon reaching the screen the cut-up foils readily flipped against it. The $24 \times 21$ inch piece sometimes folded against the screen but not the smaller pieces, because of their rigidity. In some occasions some of the smaller pieces got partially caught under the screen and, because of their inability to fold, those pieces did not flip against the screen. In conventional nuclear plant designs, the presence of a curb at the bottom of the screen would prevent this from happening and all pieces should be assumed to flip against the screen.

Tests were also done with multiple $8 \times 8$ inch and $3 \times 3$ inch foil pieces. Their relatively small size compared to the available flume floor area made interactions uncommon and those rare interactions did not appear to have significant effects on the transport. 

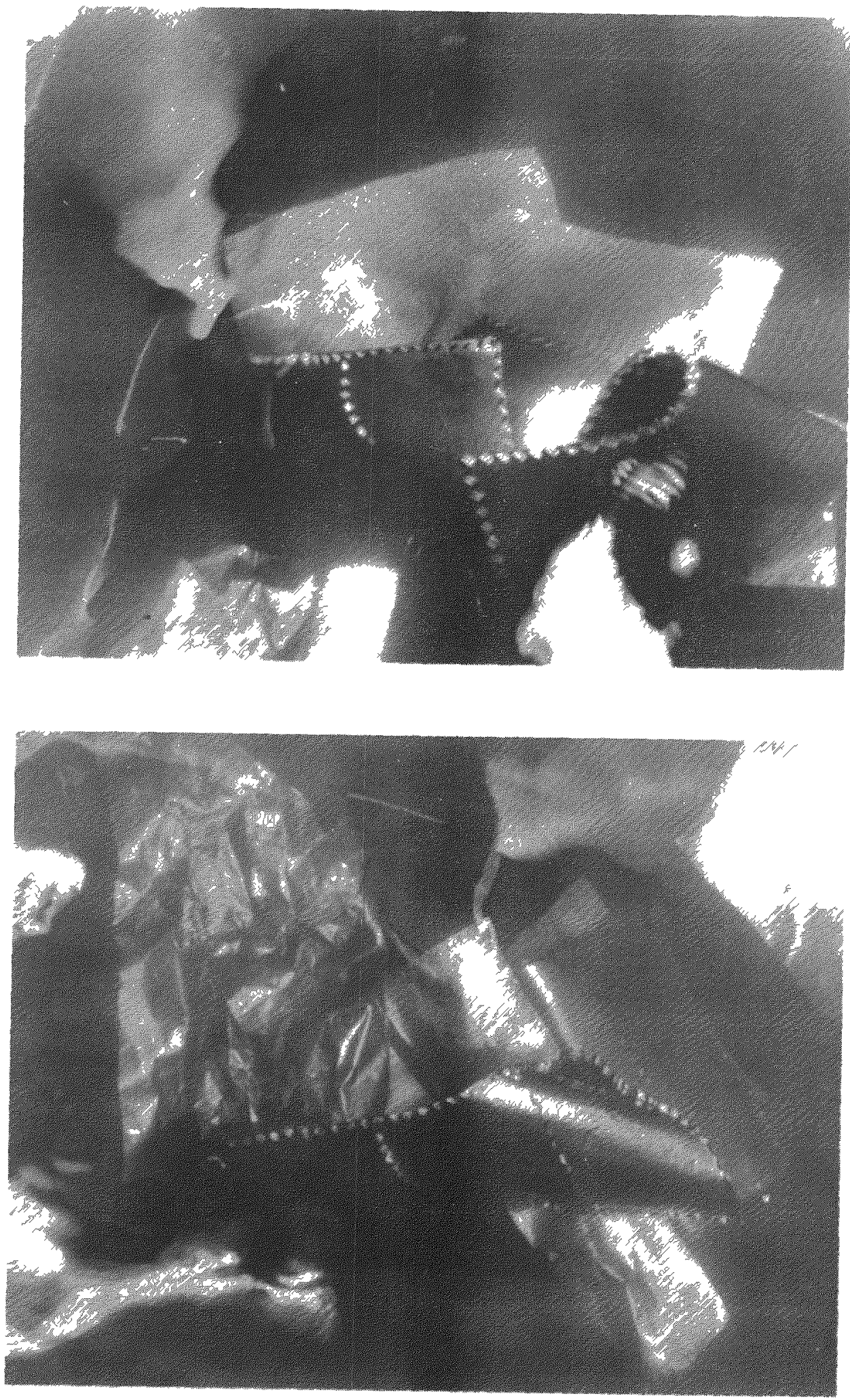

FIGURE 14 TRANSPORT OF SEVERAL INNER FOIL SHEETS (0.0025 INCH THICKNESS) 


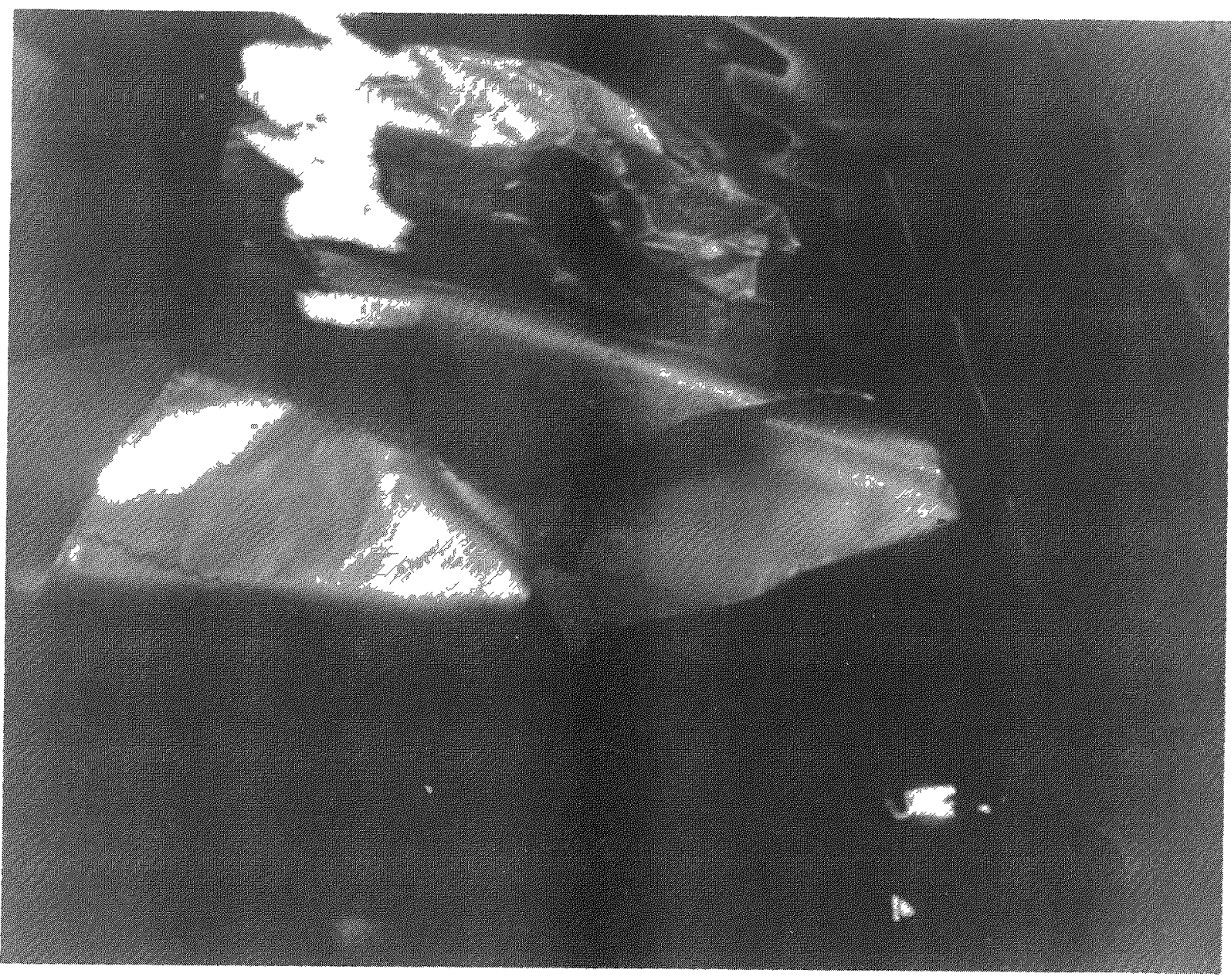

FIGURE 15 JAM OF SEVERAL INNER FOILS $(0.0025 \mathrm{INCH}$ THICKNESS) 

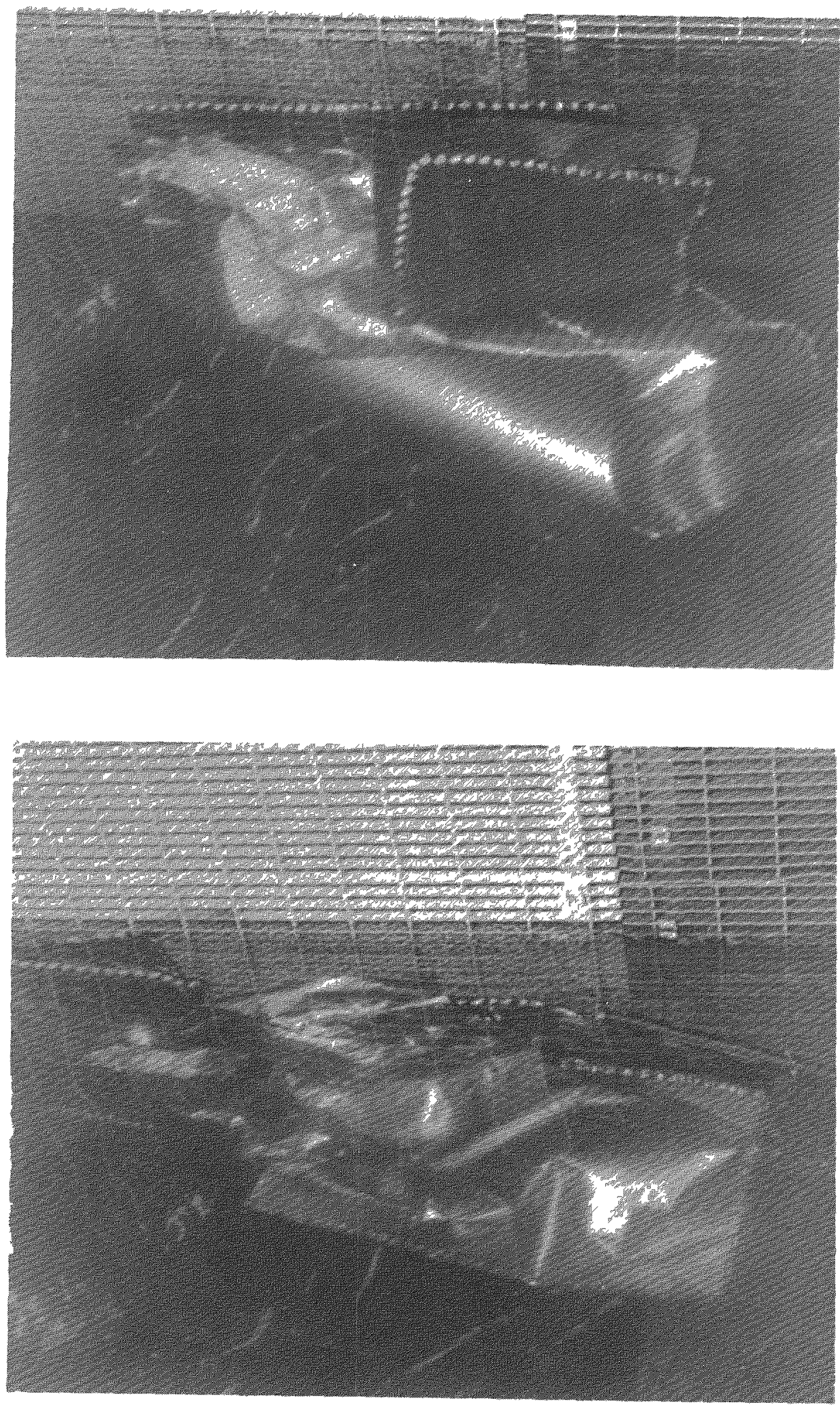

FIGURE 16 FOUR (TOP) AND FIVE (BOTTOM) INNER FOILS $(0.0025$ INCH THICKNESS) AGAINST SCREEN 


\subsubsection{Separating Crimp.}

Separating crimp from one inner foil sheet was detached and tested separately. The velocity needed to initiate the motion was $0.3 \mathrm{ft} / \mathrm{sec}$ and the velocity needed to transport the sample to the screen was $0.5 \mathrm{ft} / \mathrm{sec}$. On the screen, the crimp material produced practically no blockage.

\subsection{Stainless Steel Foil}

\subsection{Inch Thick Foil}

This foil thickness is not presently used in reactors. It was, however, tested because of availability and to add information regarding thickness dependencies.

This foil was tested in pieces approximately $12 \times 12$ inches, crumpled and uncrumpled. The flow velocities needed to initiate the motion varied from $0.20 \mathrm{ft} / \mathrm{sec}$ for crumpled material (crumpling height of approximately 6") to $0.35 \mathrm{ft} / \mathrm{sec}$ for uncrumpled material. The uncrumpled material tended to fold and tumble in its transport while the more crumpled samples, because of the resulting rigidity, tended to slide along the floor. This is consistent with the observation made for 0.0025 inch foil and described in 4.1.5-b.

Upon reaching the screen, the foil pieces readily flipped up against it and became flattened by the flow force, often folded, especially for initially uncrumpled samples.

\section{2 .20 .004 Inch Thick Foil}

This foil was tested in pieces approximately $36 \times 36$ inches. This is the largest size that can presently be expected in reflective metallic insulation jackets. Based on the results described earlier, in which the flow velocity needed to cause transport was seen to increase with decreasing foil dimensions, the $36 \times 36$ inch foils should give the lowest expectable transport velocities.

The flow velocity needed to move the $36 \times 36 \times 0.004$ inch foils was approximately $0.25 \mathrm{ft} / \mathrm{sec}$, whether crumpled or uncrumpled. The transport of the uncrumpled foils was primarily of the folding and tumbling mode observed for the flexible foils (large 0.0025 inch pieces and 0.0015 inch foils) but also sometimes of the sliding mode (with the upstream end lifted) observed for the more rigid samples (small 0.0025 inch pieces). The crumpled samples tended to follow the sliding transport mode.

When transport occurred in the folding and tumbling mode, the foils tended to fold on the screen. In one test the foil became folded on the screen without any contact with the floor (see Figure 17) indicating that the foil became water borne when reaching the screen. Since the foil folded on the screen, 

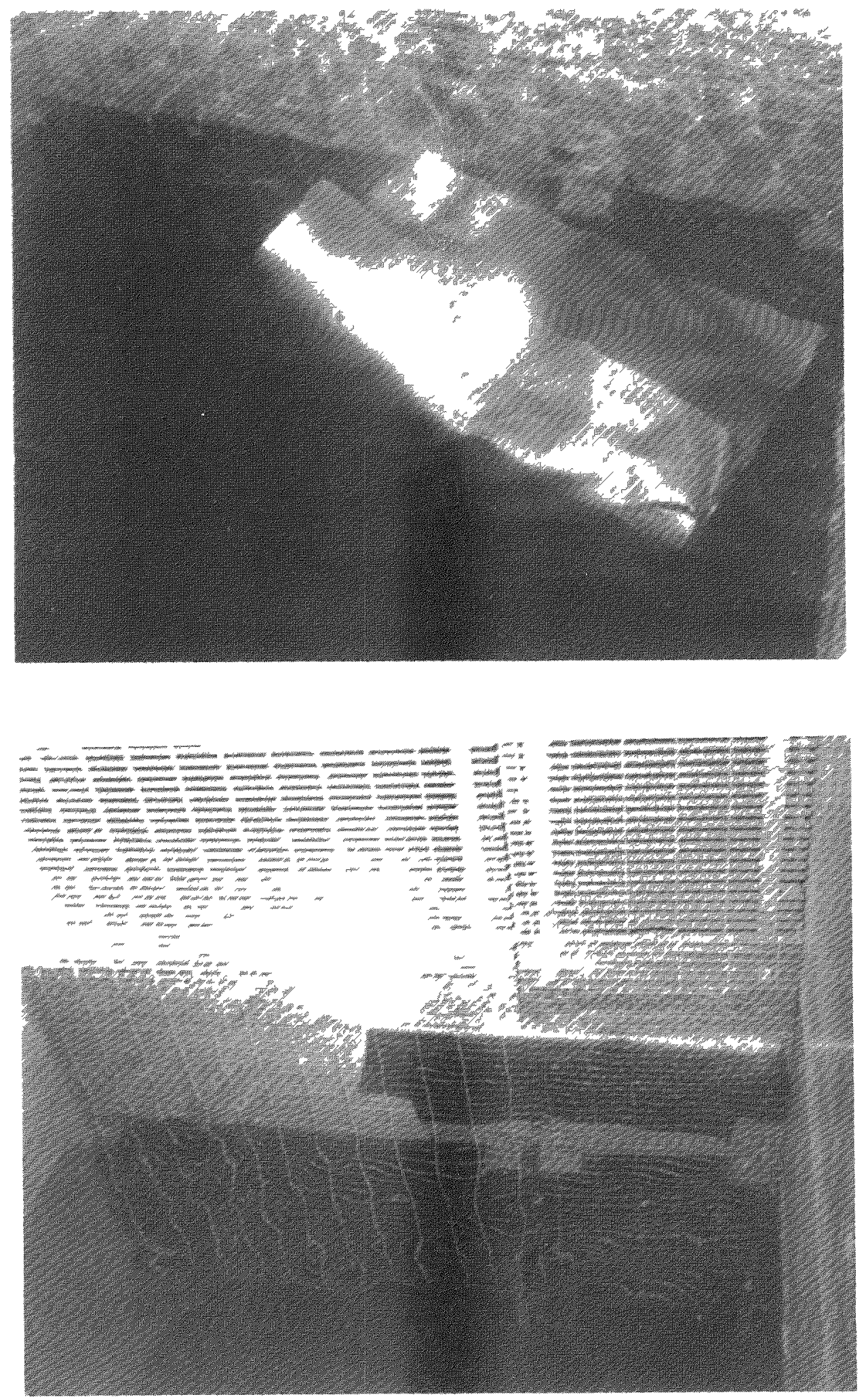

FIGURE 17 FOLDING AND TUMBLING TRANSPORT OF 0.004 INCH FOIL AND CORRESPONDING SCREEN BLOCKAGE 
however, it still did not block above its largest dimension. Photos of other blockage patterns with uncrumpled 0.004 inch foil are given in Figure 18.

Tests were also conducted with multiple foils ( 2 crumpled and 2 uncrumpled). As for the thinner foils, jamming was observed to occur needing higher velocities to unjam, up to $1.1 \mathrm{ft} / \mathrm{sec}$. Jamming did not occur in all cases, however. On the screen significant overlapping was observed; with the four foils which total area was 2.2 times that of the screen, however, up to about $80 \%$ blockage was observed in one case.

\subsection{Inch Thick Foil}

This foil was tested in pieces approximately $36 \times 36$ inches. The flow velocity needed to initiate the motion of uncrumpled samples was approximately 0.8 $\mathrm{ft} / \mathrm{sec}$ and this velocity was sufficient to transport the foils to the screen. Because of their rigidity, the foils remained unfolded during the transport, sliding along the bottom with the upstream edge slightly lifted. On the screen the foils tended not to fold, although a part often became caught under the screen and the remaining would then fold up on the screen. This is shown in Figure 19. In one case the 0.008 inch foil flipped unfolded on the screen and its top portion was above the water surface (the water depth was 32 inches).

Crumpled 0.008 inch foils transported at lower velocities than uncrumpled foils, starting to move as low as $0.4 \mathrm{ft} / \mathrm{sec}$. This velocity depended on the mode of crumpling and on the initial placement of the foil. For example, when the crumpled foils had protruding corners, the velocity needed for transport was higher if the corners were against the bottom. The flow velocity needed to transport the samples to the screen was approximately $0.5 \mathrm{ft} / \mathrm{sec}$. On the screen, the blockage depended on the crumpling mode. The flow force was usually not large enough to uncrumple the foils and flatten them on the screen, so that the blockage was often minimal.

Tests conducted with four foils (2 crumpled and 2 uncrumpled) again showed the possibility of jamming and interruption of transport. In one case, see Figure 20 , the maximum attainable velocity of about $2.0 \mathrm{ft} / \mathrm{sec}$ was not sufficient to break up the jam and the foils therefore never reached the screen. On the screen, overlapping of the foils occurred with blockages nevertheless reaching about $80 \%$ in one case. 

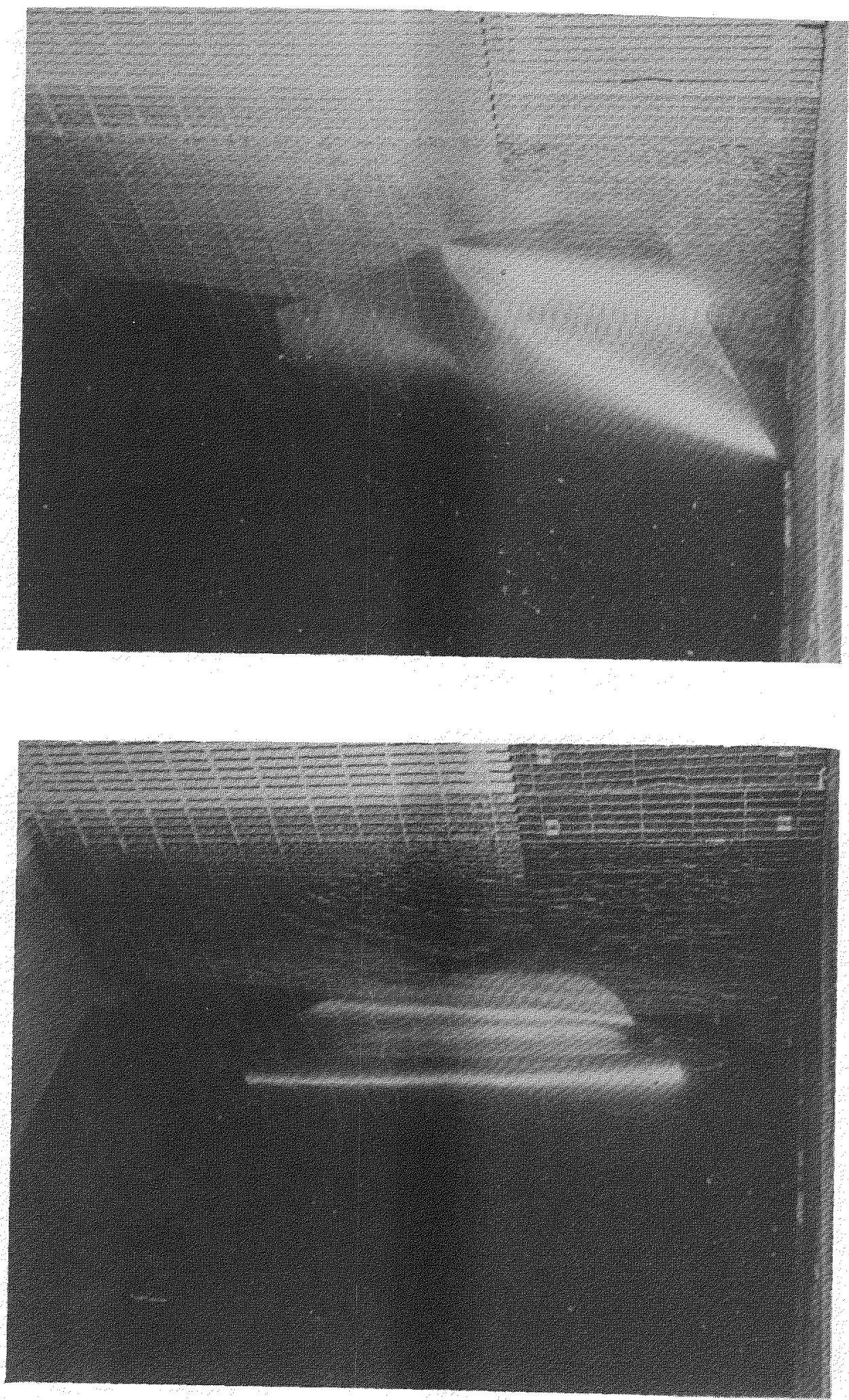

FIGURE 18 SCREEN BLOCKAGE PATTERNS OBTAINED WITH UNCRUMPLED 0.004 INCH FOILS

(36 $\times 36$ INCH SHEETS) 

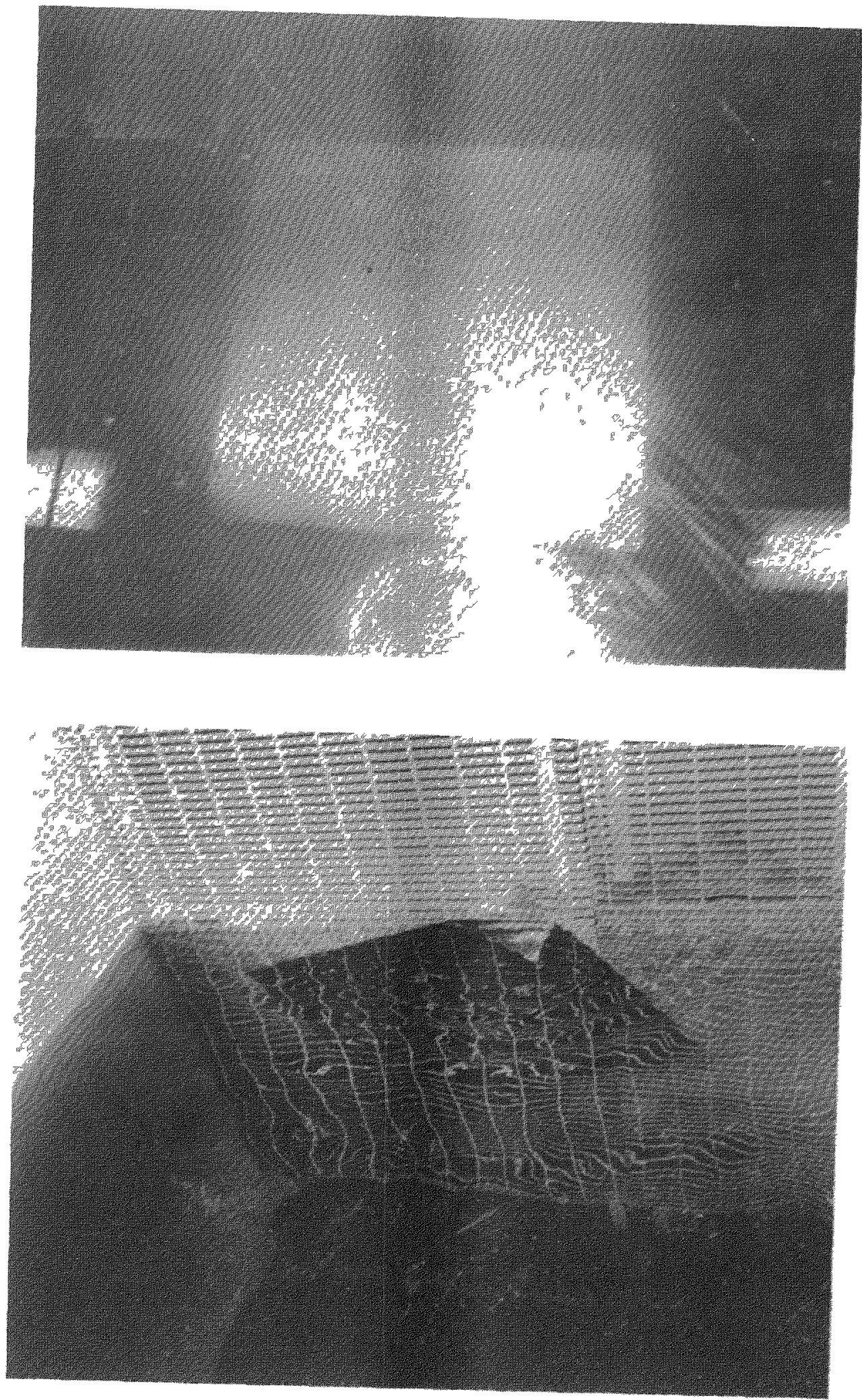

FIGURE 19 SLIDING TRANSPORT AND CORRESPONDING SCREEN BLOCKAGE OF SINGLE 0.008 INCH THICK FOIL 


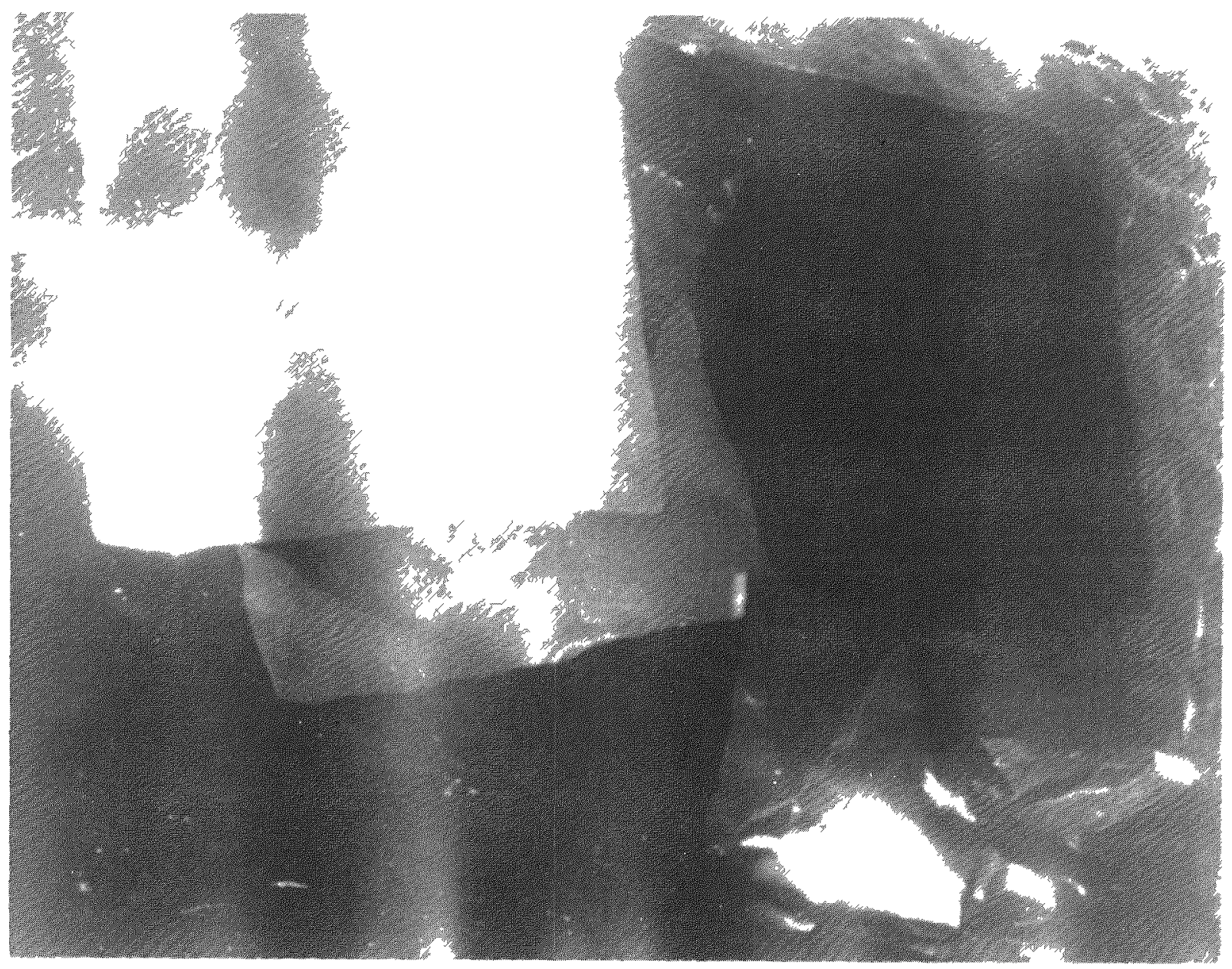

FIGURE 20 JAM OF SEVERAL 0.008 INCH FOILS. 
TABLE $4-1$

TRANSPORT AND BLOCKAGE TEST RESULTS

For 10 inch Pipe Insulation Assembly

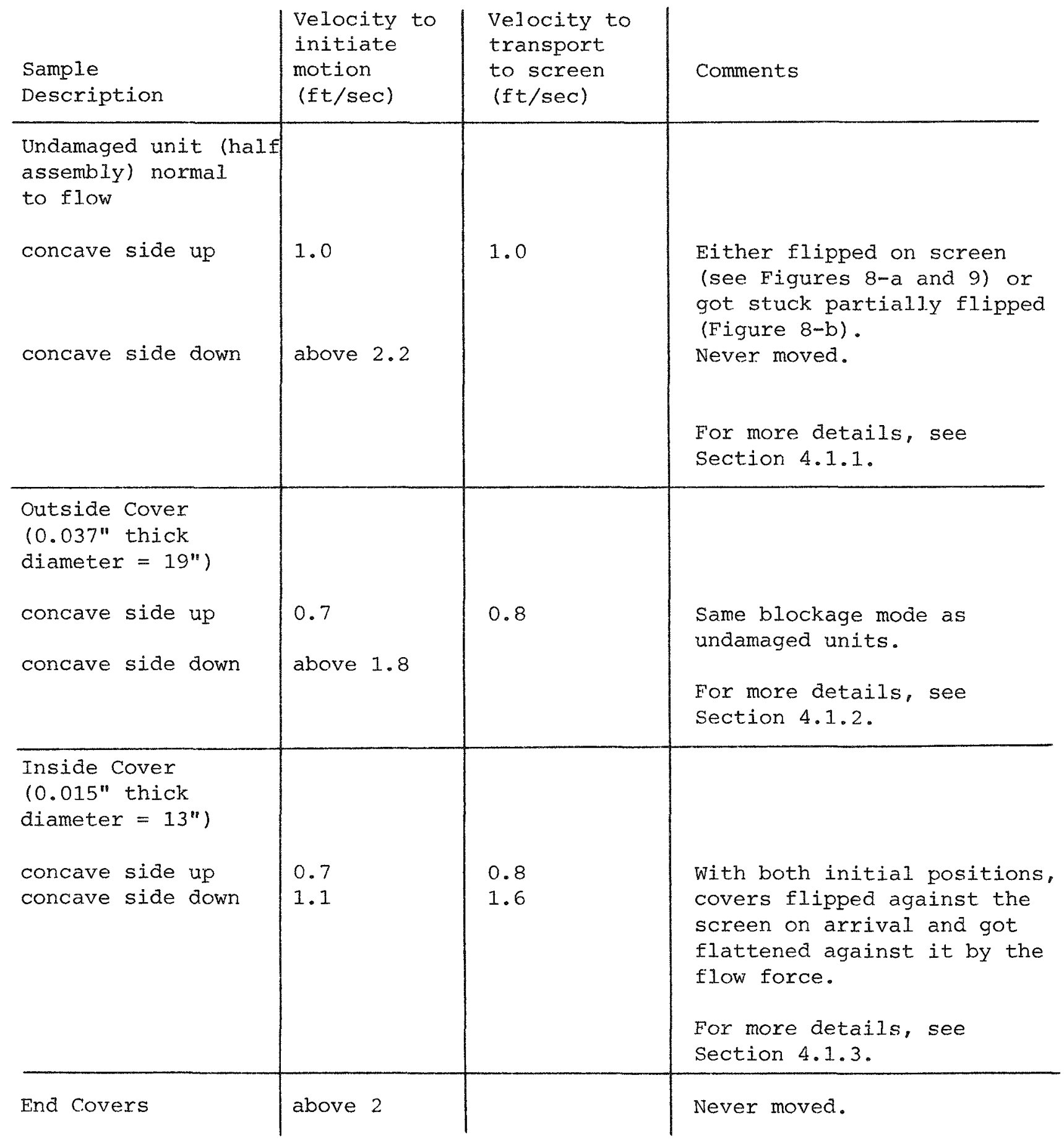




\begin{tabular}{|c|c|c|c|}
\hline $\begin{array}{l}\text { Sample } \\
\text { Description }\end{array}$ & $\begin{array}{l}\text { Velocity to } \\
\text { initiate } \\
\text { motion } \\
\text { (ft/sec) }\end{array}$ & $\begin{array}{l}\text { Velocity to } \\
\text { transport } \\
\text { to screen } \\
(\mathrm{ft} / \mathrm{sec})\end{array}$ & Comments \\
\hline $\begin{array}{l}\text { Single sheet } \\
\text { Inner Foil } \\
\left(0.0025^{\prime \prime} \text { thick) }\right. \\
\text { uncrumpled } \\
\text { with and without } \\
\text { separating crimp }\end{array}$ & 0.35 & 0.5 & $\begin{array}{l}\text { Moves in folding and tumbling } \\
\text { mode (Figure 10). } \\
\text { Flips vertically against } \\
\text { screen as soon as it } \\
\text { reaches it. (Figure 11) } \\
\text { May be folded on screen, } \\
\text { i.e., not cover full } \\
\text { sheet area. } \\
\text { Never covered screen higher } \\
\text { than maximum sheet dimension, } \\
\text { even for flow velocity of } \\
2 \text { ft/sec, and water depth } \\
\text { of } 60 \text { inches. } \\
\text { For more details, see } \\
\text { Section } 4.1 .5-a .\end{array}$ \\
\hline $\begin{array}{l}\text { Single sheet } \\
\text { Inner Foil } \\
\left(0.0025^{\prime \prime} \text { thick }\right)\end{array}$ & 0.20 & 0.25 & $\begin{array}{l}\text { Moves in folding and tumbling } \\
\text { mode. Flips against screen } \\
\text { as soon as it reaches it. } \\
\text { Gets flattened on screen } \\
\text { by current. } \\
\text { For more details, see } \\
\text { Section } 4.1 .5-b \text {. }\end{array}$ \\
\hline $\begin{array}{l}\text { Four sheets } \\
\text { inner foil } \\
\left(0.0025^{\prime \prime} \text { thick) }\right. \\
\text { two crumpled } \\
\text { two uncrumpled }\end{array}$ & 0.25 & 0.4 to 1.8 & $\begin{array}{l}\text { When numerous foil sheets } \\
\text { are used they tend to jam } \\
\text { up in piles that may need } \\
\text { high velocity to unjam. } \\
\text { Significant overlapping on } \\
\text { screen. } \\
\text { For more details, see } \\
\text { section } 4.1 .5-c \text {. }\end{array}$ \\
\hline
\end{tabular}




\begin{tabular}{|c|c|c|c|}
\hline $\begin{array}{l}\text { Sample } \\
\text { Description }\end{array}$ & $\begin{array}{l}\text { Velocity to } \\
\text { initiate } \\
\text { motion } \\
\text { (ft/sec) }\end{array}$ & $\begin{array}{l}\text { Velocity to } \\
\text { transport } \\
\text { to screen } \\
\text { (ft/sec) }\end{array}$ & Comments \\
\hline $\begin{array}{l}\text { Single cut-up sheet } \\
\text { inner foil } \\
\left(0.0025^{\prime \prime} \text { thick }\right. \\
\left.24^{\prime \prime} \times 21^{\prime \prime}\right) \\
\text { uncrumpled } \\
\text { crumpled }\end{array}$ & $\begin{array}{l}0.20 \\
0.20\end{array}$ & $\begin{array}{l}0.25 \\
0.25\end{array}$ & $\begin{array}{l}\text { Folding and tumbling } \\
\text { transport mode. Flip } \\
\text { vertically on screen } \\
\text { upon arrival, sometimes } \\
\text { folded. } \\
\text { Flip vertically on screen } \\
\text { upon arrival, sometimes } \\
\text { folded. } \\
\text { For more details, see } \\
\text { Section } 4.1 .5-d .\end{array}$ \\
\hline $\begin{array}{l}\text { Several cut-up } \\
\text { sheets inner foil } \\
\left(0.0025^{\prime \prime} \text { thick }\right. \\
\left.8^{\prime \prime} \times 8^{\prime \prime}\right) \\
\text { uncrumpled } \\
\text { crumpled }\end{array}$ & $x^{2}$ & 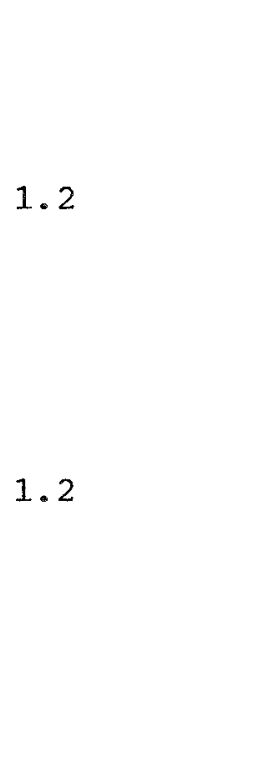 & $\begin{array}{l}\text { Pieces not folded by flow } \\
\text { as larger ones. Sliding } \\
\text { transport mode. } \\
\text { one piece reached screen at } \\
0.5 \mathrm{ft} / \mathrm{sec}-\text { all flipped } \\
\text { vertically on arrival to } \\
\text { screen. } \\
\text { One piece reached screen } \\
\text { at } 0.9 \mathrm{ft} / \mathrm{sec}-\text { all flipped } \\
\text { vertically on arrival to } \\
\text { screen. } \\
\text { For more details, see } \\
\text { Section } 4.1 .5-d .\end{array}$ \\
\hline $\begin{array}{l}\text { Several cut-up } \\
\text { sheets inner foil } \\
\left(0.0025^{\prime \prime} \text { thick }\right. \\
\left.3^{\prime \prime} \times 3^{\prime \prime}\right) \\
\text { uncrumpled }\end{array}$ & 0.8 & 2.0 & $\begin{array}{l}\text { Pieces not folded by flow } \\
\text { as larger ones. Sliding } \\
\text { transport mode. }\end{array}$ \\
\hline
\end{tabular}




\begin{tabular}{|c|c|c|c|}
\hline $\begin{array}{l}\text { Sample } \\
\text { Description }\end{array}$ & $\begin{array}{l}\text { Velocity to } \\
\text { initiate } \\
\text { motion } \\
\text { (ft/sec) }\end{array}$ & $\begin{array}{l}\text { Velocity to } \\
\text { transport } \\
\text { to screen } \\
(\mathrm{ft} / \mathrm{sec})\end{array}$ & Comments \\
\hline $\begin{array}{l}\text { Several cut-up } \\
\text { sheets inner foil } \\
\left(0.0025^{\prime \prime} \text { thick }\right. \\
3 " \times 3^{\prime \prime)} \\
\text { (continued) } \\
\text { crumpled }\end{array}$ & 0.6 & 1.0 & $\begin{array}{l}\text { Pieces flip vertically } \\
\text { on screen unless a corner } \\
\text { gets trapped under screen } \\
\text { bottom, in which case the } \\
\text { piece stays flat on bottom. } \\
\text { For more details, see } \\
\text { Section } 4.1 .5-d \text {. }\end{array}$ \\
\hline
\end{tabular}


TABLE $4-2$

\section{TRANSPORT AND BLOCKAGE TEST RESULTS \\ For Stainless Steel Foil stock}

\begin{tabular}{|c|c|c|c|}
\hline $\begin{array}{l}\text { Sample } \\
\text { Description }\end{array}$ & $\begin{array}{l}\text { Velocity to } \\
\text { initiate } \\
\text { motion } \\
(\mathrm{ft} / \mathrm{sec})\end{array}$ & $\begin{array}{l}\text { Velocity to } \\
\text { transport } \\
\text { to screen } \\
\text { (ft/sec) }\end{array}$ & Comments \\
\hline $\begin{array}{l}0.0015 \text { inch foil } \\
\text { ( } 12 \times 12 \text { inches) } \\
\text { uncrumpled } \\
\text { crumpled }\end{array}$ & $\begin{array}{l}0.35 \\
0.20\end{array}$ & $\begin{array}{l}0.50 \\
0.25\end{array}$ & $\begin{array}{l}\text { Folding and tumbling } \\
\text { transport mode, often folds } \\
\text { on the screen. } \\
\text { For more details, see } \\
\text { Section } 4.2 .1 \text {. }\end{array}$ \\
\hline $\begin{array}{l}0.0040 \text { inch foil } \\
\text { ( } 36 \times 36 \text { inches) } \\
\text { uncrumpled } \\
\text { crumpled }\end{array}$ & 0.25 & $\begin{array}{l}0.40 \\
0.35\end{array}$ & $\begin{array}{l}\text { Folding and tumbling } \\
\text { transport mode, occasionally } \\
\text { sliding. Flips on screen } \\
\text { upon arrival, often folded. } \\
\text { Folding and tumbling or } \\
\text { sliding transport mode. }\end{array}$ \\
\hline $\begin{array}{l}\text { multiple sheets } \\
\text { ( } 2 \text { crumpled } \\
2 \text { uncrumpled) }\end{array}$ & 0.25 & 0.9 to 1.1 & $\begin{array}{l}\text { Foil interactions often } \\
\text { create jams needing higher } \\
\text { velocities to break up. } \\
\text { Significant overlapping on } \\
\text { screen. Blockage up to } \\
\text { about } 80 \% \text { observed. } \\
\text { For more details, see } \\
\text { Section } 4.2 .2 \text {. }\end{array}$ \\
\hline $\begin{array}{l}0.0080 \text { inch foil } \\
(36 \times 36 \text { inches) } \\
\text { uncrumpled }\end{array}$ & 0.40 & 0.50 & $\begin{array}{l}\text { Sliding transport mode. } \\
\text { Flips against screen on } \\
\text { arrival, folds only if foil } \\
\text { becomes partially caught } \\
\text { under screen. } \\
\text { Sliding transport mode. } \\
\text { Does not become flattened } \\
\text { against screen and therefore } \\
\text { usually produces small } \\
\text { blockage. }\end{array}$ \\
\hline
\end{tabular}




\begin{tabular}{|c|c|c|c|}
\hline $\begin{array}{l}\text { Sample } \\
\text { Description }\end{array}$ & $\begin{array}{l}\text { Velocity to } \\
\text { initiate } \\
\text { motion } \\
\text { (ft/sec) }\end{array}$ & $\begin{array}{l}\text { Velocity to } \\
\text { transport } \\
\text { to screen } \\
\text { (ft/sec) }\end{array}$ & Comments \\
\hline $\begin{array}{l}0.0080 \text { inch foil } \\
\text { (continued) } \\
\text { multiple sheets } \\
\text { ( } 2 \text { crumpled } \\
2 \text { uncrumpled) }\end{array}$ & 0.40 & $\begin{array}{l}0.90 \text { to } \\
\text { above } 2.0\end{array}$ & $\begin{array}{l}\text { Foil interaction often } \\
\text { creates jams needing higher } \\
\text { velocities to break up. } \\
\text { Significant overlapping on } \\
\text { screen. Blockage up to } \\
\text { about } 80 \% \text { observed. } \\
\text { For more details, see } \\
\text { Section } 4.2 .3\end{array}$ \\
\hline
\end{tabular}


REFERENCES

1) Brocard, D. N., "Buoyancy, Transport and Head Loss of Fibrous Reactor Insulation," U.S. Regulatory Commission Report NUREG/CR-2982 (Also Sandia National Laboratory Report SAND82-7205) Revision 1, July 1983.

2) Brocard, D. N., "Transport and Head Loss Tests of Owens Corning NUKON Fiberglass Insulation," Report No. 110-83, Alden Research Laboratory, Holden, MA 01520, November 1983.

3) Wysocki, J., and Kolbe, R., "Methodology for Evaluation of Insulation Debris Effects," U.S. Nuclear Regulatory Commission, Report NUREG/CR-2791 (also Sandia National Laboratory Report SAND82-7067), September 1982. 